Andrzej Krawiec

Uniwersytet Jagielloński, Kraków

ORCID: 0000-0002-3230-2201

e-mail: krawiecandrzej@gmail.com

\title{
Sztuka jako objawienie Życia w perspektywie fenomenologii Michela Henry'ego
}

DOI: http://dx.doi.org/10.12775/RF.2021.004

\section{Wprowadzenie}

Na aspekt niewidzialności w sztuce zwracał uwagę w ostatnich swoich pracach Maurice Merleau-Ponty ${ }^{1}$. Choć Michel Henry bardzo rzadko odwoływał się do tekstów autora Widzialne i niewidzialne, to jednak jego stanowisko kształtowało się w dużej mierze poprzez niejawną z nim polemikę. Akcentując nieprzedmiotowość, wydarzeniowość i niewidzialność sztuki, Michel Henry bliski jest w poglądach takim francuskim fenomenologom jak Henri Maldiney czy Jean-Luc Marion². Krytycznie

1 Por. Maurice Merleau-Ponty, Oko i umyst, przeł. Stanisław Cichowicz, w: Maurice Merleau-Ponty, Oko i umysł. Szkice o malarstwie, przeł. Stanisław Cichowicz i in. (Gdańsk: Wydawnictwo Słowo obraz/terytoria, 1996), 15-67; Maurice Merleau-Ponty, Widzialne i niewidzialne, przeł. Małgorzata Kowalska, Jacek Migasiński, Renata Lis, Iwona Lorenc (Warszawa: Fundacja Aletheia, 1996). Por. także Monika Murawska, „Sztuka, która pozwala zobaczyć niewidzialne. Maurice Merleau-Ponty o malarstwie Cézanne'a i Michel Henry o abstrakcji Kandinskiego", Przeglad Filozoficzno-Literacki 14 (2006): 133-154; Monika Murawska, Filozofowanie z zamkniętymi oczami. Fenomenologia ciała Michela Henry'ego (Wrocław: Wydawnictwo Uniwersytetu Wrocławskiego, 2011), 208-233.

2 Por. Monika Murawska, „Obnażyć sztukę. Fenomen dzieła sztuki w fenomenologii Jeana Luca Mariona i Henriego Maldineya", w: Fenomen i przedstawienie. Francuska estetyka fenomenologiczna. Założenia/zastosowania/konteksty, red. Iwona Lorenc i in. 
ustosunkowywał się do niemieckiej tradycji fenomenologicznej - intencjonalnej fenomenologii Edmunda Husserla oraz myślenia sztuki Martina Heideggera - lecz można mieć wątpliwości, czy są to koncepcje przeciwstawne, czy też może fenomenologia Henry'ego jest rozwinięciem i radykalizacją idei „powrotu do rzeczy samych”, a także powrotu do najbardziej własnego, zindywidualizowanego bycia sobą (Siebie, Selbst) ${ }^{3}$. To prawda, że immanentna rzeczywistość „świata życia” (monde de la vie, monde-de-la-vie) u Henry'ego nie jest tym samym, co Lebenswelt u Husserla ${ }^{4}$, lecz pod tymi terminami kryją się u obu autorów podobne założenia przedpredykatywnego i afektywnego doznawania, resp. afekcji przeddania. Z kolei afektywne doznawanie niewidzialnego życia przez każdą Sobość (Soi) wykazuje duże pokrewieństwo z najbardziej własną i właściwą (autentyczną) możnością egzystencyjną bycia Sobą (Selbst). Wydaje się więc, że opozycja Henry'ego wobec przynajmniej niektórych koncepcji filozoficznych Husserla i Heideggera jest niekiedy mniejsza, niż deklaruje to sam autor Voir l'invisible.

Najważniejszym punktem odniesienia w rozważaniach Henry'ego o sztuce jest twórczość i prace teoretyczne Wasyla Kandyńskiego ${ }^{5}$. Wydana w 1912 roku praca Kandyńskiego O duchowości w sztuce stanowi swoisty "katechizm” artystyczny, pouczający czytelnika, w jaki sposób sztuka powinna być odbierana oraz jakie ma znaczenie w życiu człowieka. Istotne dla związku z filozofią Henry'ego jest również to, że można w niej dostrzec wpływy popularnej wówczas myśli teozoficznej ${ }^{6}$. Druga praca Kandyńskiego - Punkt i linia a płaszczyzna - pochodzi z 1926 roku i jest to precyzyjna analiza podstawowych elementów malarskich, na-

(Warszawa: Wydawnictwo IFiS PAN, 2012), 265-286; Anna Yampolskaya, „Metamorphoses of the Subject: Kandinsky Interpreted by Michel Henry and Henri Maldiney", Avant 9/2 (2018): 157-167.

3 Por. Michel Henry, "Sztuka i fenomenologia życia”, przeł. Monika Murawska, Przegląd Filozoficzno-Literacki 34 (2012): 157-160, 168, 172. Por. także Iwona Lorenc, „Ścieżki ku rzeczom samym współczesnej fenomenologii francuskiej”, w: Fenomenologia francuska. Rozpoznania, interpretacje, rozwinięcia, red. Iwona Lorenc i in. (Warszawa: IFiS PAN, 2006), 66; Marek Pokropski, „Husserl i Henry - spór o intencjonalność", Przeglad Filozoficzno-Literacki 34 (2012): 249; Michel Henry, O fenomenologii, przeł. Marek Drwięga (Warszawa: Wydawnictwo IFiS PAN, 2007), 91-94.

${ }^{4}$ Por. Edmund Husserl, Doświadczenie i sąd, przeł. Bogdan Baran (Warszawa: Fundacja Aletheia, 2013), 49-64. Por. także Philippe Capelle, „Fenomenologia i życie w myśli Michela Henry'ego", przeł. Siostry Betanki, w: Michel Henry - fenomenolog życia, red. Andrzej Gielarowski, Robert Grzywacz (Kraków: Wyższa Szkoła Filozoficzno-Pedagogiczna „Ignatianum”, Wydawnictwo WAM, 2010), 31; Monika Murawska, „Filozofia źródłowa »contra« antropologia. Fenomen kultury w ujęciu Michela Henry'ego", w: Michel Henry - fenomenolog życia, red. Andrzej Gielarowski, Robert Grzywacz (Kraków: Wyższa Szkoła Filozoficzno-Pedagogiczna „Ignatianum”, Wydawnictwo WAM, 2010), 130-131.

5 Por. Henry, „Sztuka i fenomenologia życia”: 161.

${ }^{6}$ Por. Kandyński, O duchowości w sztuce, 42-43. 
pisana technicznym językiem i będąca $\mathrm{w}$ zamyśle podręcznikiem dla studentów Bauhausu? . Trzecia praca Kandyńskiego - Eseje o sztuce i artystach - została wydana pośmiertnie w 1955 roku i stanowi zbiór krótkich tekstów z lat 1912-1943, zebranych przez ucznia i wydawcę prac Kandyńskiego - Maxa Billa. We wszystkich tych tekstach Michel Henry odnajduje inspiracje dla utworzenia nie tylko własnej fenomenologii sztuki, ale i fenomenologii życia8.

Pokrewieństwo fenomenologii życia Michela Henry'ego oraz filozofii sztuki Wasyla Kandyńskiego uwidacznia się w opozycyjnym zestawieniu materialności świata i duchowości życia. W odczuwaniu wewnętrznego „brzmienia” (Klang) dzieła sztuki Henry odnajduje odpowiednik afektywnego doznawania (pathos) życia fenomenologicznego. To wewnętrzne doznanie, które abstrahuje od rzeczy i świata, prowadzi do zbudowania szczególnej koncepcji „podmiotu” (Sobości, Soi) ugruntowanej w radykalnej immanencji.

Sztuka objawia niewidzialne życie fenomenologiczne, którego żywiołem jest afektywność transcendentalna. Oznacza to, że przeżywanie dzieł sztuki staje się dostępem do źródłowego doznania życia, co nierozerwalnie wiąże się także ze sferą aksjologiczną duchowości człowieka. Sztuka w perspektywie fenomenologii życia Michela Henry'ego dotyka ponadto wymiaru świętości, a w końcowym okresie twórczości Henry'ego wiąże się z chrystologią? jekt fenomenologii życia Henry'ego jest niezwykle spójny, to dostęp poznawczy do istoty życia, które objawia się w afektywnej doznaniowości, rodzi wiele znaków zapytania. Doświadczenie zarówno głębokiej treści

7 Agnieszka Rejniak-Majewska napisze w posłowiu do współczesnego wydania tej pracy: „Organicystyczny światopogląd przenika całość tej rozprawy, łącząc ją z nurtem wpływowego w kręgu twórców Bauhausu biocentryzmu i tradycją romantycznej filozofii natury"; Agnieszka Rejniak-Majewska, „Chaosmos, czyli o gramatyce i fizjonomice form", w: Wasyl Kandyński, Punkt i linia a płaszczyzna, przeł. Stanisław Fijałkowski (Łódź: Wydawnictwo Oficyna, 2019), 200. Por. „Idee te przesłoniły w latach 20. wcześniejsze teozoficzne inspiracje Kandyńskiego, najbardziej czytelne w jego traktacie O duchowości w sztuce (1912); nie tyle jednak wyparły one jego wizję "nowej duchowości«, co wyznaczyły jej nową formułę"; tamże, 200, przypis dolny. Por. także tamże, 202. Zauważmy jednak przy tym, że i odwrotnie, także w książce O duchowości w sztuce można odnaleźć analizy, przypominające te z rozprawy Punkt i linia a płaszczyzna; por. analizę bieli i czerni w: Kandyński, O duchowości w sztuce, 92-93.

8 Por. Henry, „Sztuka i fenomenologia życia”: 165. Warto zaznaczyć, że w opinii Henry'ego prace teoretyczne Kandyńskiego ściśle odpowiadają analizom fenomenologicznym; por. Michel Henry, Voir l'invisible. Sur Kandinsky (Paris: Quadrige/PUF, 2005), 50, 87, 132-133.

9 Pozostaje natomiast kwestią nierozstrzygalną, czy w takiej perspektywie przeżywający sztukę podmiot ulega "metafizycznej metamorfozie”, co zdaje się sugerować Anna Yampolskaya; por. Yampolskaya, „Metamorphoses”: 166. 
dzieł sztuki, jak i żyjącej Sobości w jej radykalnej immanencji jest epistemicznie mgliste i niestabilne, a ponadto niewyrażalne językowo. Ta śmiała koncepcja filozofii sztuki natrafia ostatecznie na trudności, których nie sposób rozwiązać na gruncie tradycyjnie pojmowanej estetyki filozoficznej.

Niniejszy artykuł składa się z trzech etapów rozważań. W pierwszej części artykułu przedstawię najważniejsze aspekty filozofii sztuki Wasyla Kandyńskiego, w których najwyraźniej uwidacznia się pokrewieństwo artystycznych deklaracji Kandyńskiego z fenomenologią sztuki Michela Henry'ego. W kolejnej części przeanalizuję fenomenologię sztuki Michela Henry'ego w szerszej perspektywie jego fenomenologii Życia. Natomiast w trzeciej części wskażę na istotne ograniczenia ontologiczne, epistemologiczne oraz aksjologiczne obu teorii - Kandyńskiego i Henry'ego.

\section{Wewnętrzna duchowość dzieła szłuki (Kandyński)}

Analizując prace teoretyczne Kandyńskiego na temat malarstwa, nie sposób nie zwrócić uwagi na jego liczne odniesienia do innych sztuk zwłaszcza muzyki ${ }^{10}$. W jego pismach łatwo dostrzec wpływ filozofii sztuki Artura Schopenhauera, która promowała muzykę jako tę najbardziej „,czystą", przez co była uważana za ideał duchowości i niematerialności ${ }^{11}$. Atmosfera twórcza w pierwszych dekadach XX wieku niezwykle sprzyjała kontaktom i wymianie poglądów artystów odmiennych dziedzin artystycznych, dlatego nie bez wpływu na poglądy Kandyńskiego pozostała jego przyjaźń z kompozytorem - a także malarzem - Arnoldem Schönbergiem, którego darzył dużym uznaniem ${ }^{12}$.

Charakterystycznym terminem o "muzycznym” rodowodzie, którego używał Kandyński, był Klang, co w zależności od kontekstu tłumaczono na język polski zazwyczaj jako brzmienie, dźwięk, wydźwięk, ton, wyraz, nastrój, wrażenie, znaczenie lub sens. Warto przy tym zauważyć, że termin „sonorystyka”, czyli aspekt jakości brzmieniowych

${ }^{10}$ Por. Wasyl Kandyński, Eseje o sztuce i artystach, przeł. Ewa Sagan (Kraków: Politechnika Krakowska im. Tadeusza Kościuszki, 1991), 135; Kandyński, O duchowości w sztuce, 53-54.

11 Por. Kandyński, Eseje o sztuce i artystach, 147.

12 Por. tamże, 90; Rejniak-Majewska, Chaosmos, 208-209; Wasyl Kandyński, Obrazy, przeł. Jerzy Stankiewicz, w: Luigi Rognoni, Wiedeńska szkoła muzyczna, przeł. Henryk Krzeczkowski (Kraków: Polskie Wydawnictwo Muzyczne, 1978), 481-484; Arnold Schönberg, Wassily Kandinsky, Briefe, Bilder und Dokumente einer außergewöhnlichen Begegnung, red. Jelena Hahl-Koch (Salzburg-Wien: Residenz Verlag, 1980), 19, 35, 71. Dodajmy, że Harmonielehre Arnolda Schönberga powstało w tym samym roku, co Über das Geistige in der Kunst Kandyńskiego. 
poszczególnych instrumentów muzycznych, często bywa w literaturze muzykologicznej zastępowany terminem „kolorystyka”, a już zupełnie powszechnie używa się w muzycznej sztuce wykonawczej takich określeń zapożyczonych ze sztuk plastycznych, jak: "jasno", "jaskrawie", „,metalicznie", ,ciemno", ,ostro", , przestrzennie”, , ,twardo”, , miękko", "płytko" czy "głęboko". Kandyński na sposób muzyczny używa również takich wyrażeń jak „napięcie” czy „kierunek”, co w muzyce odpowiada przede wszystkim określeniom piano lub forte oraz crescendo i diminuendo. Przede wszystkim, lecz nie tylko, ponieważ napięcie oraz kierunek w dziele muzycznym tworzone są nie wyłącznie poprzez aspekt dynamiczny, lecz także poprzez pozostałe elementy dzieła: melodyczne, rytmiczne, harmoniczne, agogiczne, artykulacyjne i sonorystyczne. Te pokrewieństwa malarstwa i muzyki - nie tylko terminologiczne, ale wynikające z tej samej i wspólnej natury odmiennych dziedzin artystycznych - pomogły Kandyńskiemu odróżnić widzialne/słyszalne elementy dzieła od jego wewnętrznej treści, czyli - inaczej mówiąc - zewnętrzny wygląd/wykonanie dzieła od jego wewnętrznego wyrazu/brzmienia $(\text { Klang })^{13}$.

Dla Kandyńskiego naczelnym imperatywem "prawa duchowego" w sztuce była „zasada wewnętrznej konieczności”, którą można rozumieć na trzy sposoby. Po pierwsze dzieło sztuki może być uzewnętrznieniem wewnętrznych przeżyć jego twórcy. Po drugie dzieło sztuki może wyrażać język, styl i ducha swojej epoki. I po trzecie artysta, służąc sztuce, może budować jej własne wartości - odwieczne i zawsze aktualne dla wszystkich ludzi, widoczne w wielkich dziełach artystów każdej epoki ${ }^{14}$. Trzeciego rozumienia imperatywu twórczego nie można jednak mylić z modnym na początku XX wieku hasłem „sztuka dla sztuki" (l'art pour l'art), które Kandyński zdecydowanie krytykował ${ }^{15}$. Forma dzieła stanowi dla niego środek do celowego wzruszania ludzkiej duszy, dlatego sztuka nie może być odseparowana od wewnętrznego i afektywnego przeżycia artysty i odbiorcy ${ }^{16}$. Pierwsze dwa sposoby rozumienia „zasady wewnętrznej konieczności” i działania według niej mają charakter subiektywny, a tylko trzeci jest tym, co odwiecznie obiektywne i uzewnętrzniające się poprzez to, co czasowe i subiektywne. Zasada wewnętrznej konieczności jest więc w swej najgłębszej istocie

${ }^{13}$ Choć Kandyński wielokrotnie mówił o słyszeniu barw czy widzeniu dźwięków, to nie należy z tego powodu zbyt pochopnie wnioskować, że sam był synestetykiem. Por. jego analizy ",asocjacji”; Kandyński, O duchowości w sztuce, 59-62, 87, przypis dolny; Kandyński, Eseje o sztuce i artystach, 135-137.

${ }_{14}$ Por. Kandyński, O duchowości w sztuce, 14, 23, 76-77; Kandyński, Eseje o sztuce i artystach, 12; Wasyl Kandyński, Punkt i linia a płaszczyzna, przeł. Stanisław Fijałkowski (Łódź: Wydawnictwo Oficyna, 2019), 142-143.

${ }_{15}$ Por. Kandyński, O duchowości w sztuce, 27, 35, 125.

16 Por. tamże, 67, 72, 125; Kandyński, Punkt i linia a płaszczyzna, 38. 
pokonywaniem subiektywnego przez obiektywne ${ }^{17}$. Przytoczmy znamienną wypowiedź Kandyńskiego:

W gruncie rzeczy (...) każde poważne dzieło wyraża spokój. Ta wzniosła cisza (szlachetność) nie jest łatwo dostrzegalna przez współczesnych. Każde głębokie dzieło wewnętrznie brzmi tak, jak spokojnie i w dystyngowany sposób wypowiedziane słowa: „Oto jestem”. Ich dźwięk unosi się ponad wiekami ${ }^{18}$.

Zasada wewnętrznej konieczności nie oznacza przymusu i nie znosi wolności artysty, ponieważ temu wolno korzystać z każdej formy jako środka wyrazu wewnętrznej treści dzieła. Kandyński napisze również: "Święte są wszystkie środki, jeżeli są wewnętrznie konieczne"19. Nieco później doda natomiast:

Równocześnie jednak jest ta wolność jedną z najcięższych niewoli, ponieważ wszelkie możliwości otwierające się pomiędzy jej granicami, na obu granicach i poza granicami, wyrastają z jednego i tego samego korzenia kategorycznego imperatywu wewnętrznej konieczności $i^{20}$.

Oznacza to, że artysta może w wolnym akcie twórczym poddać się zasadzie wewnętrznej konieczności, by usłyszeć wewnętrzny głos dzieła, rezygnując z tego, co przypadkowe i zewnętrzne. $Z$ kolei proces odbiorczy dzieła sztuki wydaje się odtwarzaniem procesu twórczego artysty i docieraniem do wewnętrznej treści dzieła poprzez jego zewnętrzne elementy (formę) $)^{21}$.

Według Kandyńskiego powszechne panowanie materializmu wykształciło nieodpowiedni typ odbiorcy sztuki, który w dziele szuka wszystkiego (temperamentu artysty, elementów przyrody, odmalowywania nastrojów itp.), tylko nie "własnego doznania żywego dzieła" 22 . Kandyński ubolewał, że współczesny odbiorca sztuki zatracił zdolność słyszenia tego, co znajduje się pod powierzchnią zjawisk, a więc wewnętrznego głosu dzieła. Przyczynę tej dysfunkcji upatrywał w rozwoju technologiczno-cywilizacyjnym, materialistycznej metodologii

17 Por. Kandyński, O duchowości w sztuce, 78-79.

18 Tamże, 132, przypis dolny. Por. także Kandyński, Eseje o sztuce $i$ artystach, $115-118$.

19 Kandyński, O duchowości w sztuce, 80.

20 Tamże, 119.

${ }^{21}$ Por. Kandyński, Eseje o sztuce $i$ artystach, 31; Henry, „Sztuka i fenomenologia życia": 167. W tym punkcie koncepcja Kandyńskiego wykazuje duże podobieństwo do teorii estetycznej Witkacego; por. Stanisław Ignacy Witkiewicz, Nowe formy w malarstwie $i$ wynikajace stąd nieporozumienia. Szkice estetyczne (Warszawa: PIW, 2002), 19-23. Do kwestii tej powrócimy jeszcze później.

${ }^{22}$ Kandyński, O duchowości w sztuce, 113. 
nauk oraz zmianach $\mathrm{w}$ sposobie codziennego życia, które stawało się coraz bardziej nastawione na ułatwienia i szybkie osiąganie praktycznych celów. Należy zaznaczyć, że choć stosunek Kandyńskiego do nauki był krytyczny, to jednak nie negatywny. Negatywnie wypowiadał się on jedynie o jednostronnym, materialistycznym podejściu nauk do badanych przedmiotów/fenomenów, ale nie krytykował on nauki jako takiej - wręcz wieszczył jej szerokie zastosowanie również $\mathrm{w}$ badaniu fenomenów sztuki ${ }^{23}$. Wierzył on, że rozwój nauk przezwycięży materializm i różne odmiany pozytywizmu, a następnie rozwiąże najbardziej tajemnicze zagadki immaterialności, spirytualizmu czy duchowości. Ponadto, co wielokrotnie zaznaczał, każdy akt twórczy, w którym najistotniejszą rolę wiedzie intuicja artystyczna (uczucie), nie może być pozbawiony „mózgowej kalkulacji”24, dlatego nie stawiał rozwojowi nauk żadnych granic. Wydaje się więc, że jego diagnoza kryzysu kultury nie była aż tak pesymistyczna, czy wręcz katastroficzna, jak przedstawiona w podobnym czasie przez Oswalda Spenglera (1918-1922) ${ }^{25}$, Stanisława Ignacego Witkiewicza (1919) ${ }^{26}$, Edmunda Husserla (1935) ${ }^{27}$ czy już znacznie później przez Lewisa Mumforda $(1967 / 1970)^{28}$ i wreszcie przez Michela Henry'ego (1987) ${ }^{29}$.

Według Kandyńskiego ludzkość dzieli się na dwie grupy, tj. na tych, którzy oprócz materialności uznają niematerialność (duchowość), oraz tych, którzy uznają tylko materialność - dla tej drugiej grupy ludzi sztuka mogłaby w ogóle nie istniećc ${ }^{30}$. Kandyński napisze:

Człowiek jest „dziś" bez reszty opanowany przez zewnętrzny aspekt rzeczy; to, co wewnętrzne, jest dla niego martwe. Jest to ostatni stopień

${ }^{23}$ Por. tamże, 121; Kandyński, Eseje o sztuce i artystach, 105.

${ }^{24}$ Por. Kandyński, O duchowości w sztuce, 81; Kandyński, Eseje o sztuce i artystach, 98, 105-106, 113, 150, 153; Rejniak-Majewska, Chaosmos, 200.

${ }^{25}$ Oswald Spengler, Zmierzch Zachodu, przeł. Józef Marzęcki (Warszawa: Wydawnictwo Aletheia, 2014).

26 Witkiewicz, Nowe formy w malarstwie, 143-214.

${ }^{27}$ Edmund Husserl, Kryzys nauk europejskich i fenomenologia transcendentalna, przeł. Sławomira Walczewska (Kraków: Vis-à-vis Etiuda, 2017).

${ }^{28}$ Lewis Mumford, Mit maszyny, t. 1, przeł. Michał Szczubiałka (Warszawa: Wydawnictwo Naukowe PWN, 2012); Lewis Mumford, Mit maszyny, t. 2, przeł. Michał Szczubiałka (Warszawa: Wydawnictwo Naukowe PWN, 2014). Por. James Hart, ",Teoria fenomenologiczna i krytyka kultury. Czytanie La Barbarie Michela Henry'ego", przeł. Paulina Sosnowska, Przeglad Filozoficzno-Literacki 34 (2012): 373.

${ }_{29}$ Michel Henry, La barbarie (Paris: Quadrige/ PUF, 2004). Oczywiście brak entuzjazmu i zaufania wobec rozkwitu scjentyzmu był wyrażany także przed Kandyńskim w XIX wieku, czego przykładem może być chociażby Arthur Schopenhauer; por. Arthur Schopenhauer, Świat jako wola i przedstawienie, t. 2, przeł. Jan Garewicz (Warszawa: Wydawnictwo Naukowe PWN, 1995), 226-269.

${ }^{30}$ Por. Kandyński, Punkt i linia a płaszczyzna, 33-34; Kandyński, Eseje o sztuce i artystach, 13. 
upadku, ostatni krok w ślepej uliczce - dawniej mówiło się zresztą o „otchłani”, dziś wystarcza skromniejsze określenie „ślepa uliczka”31.

Według diagnozy Kandyńskiego współczesny człowiek zatracił zdolność widzenia wewnętrznych treści pod zewnętrzną formą rzeczy, a jego dusza stała się zaskorupiała i niewrażliwa na wewnętrzne tętno, które bije pod ich powłoką ${ }^{32}$. Jednocześnie człowiek ten przestał zadowalać się jedynie tym, co pozorne, i zaczynało rosnąć w nim pragnienie zobaczenia i usłyszenia głębszej duchowości, dlatego poszukuje sposobu, dzięki któremu mógłby wybudzić się ze śpiączki do prawdziwego $\dot{z ̇ y c i a}^{33}$. I tak sztuka jest jednym ze sposobów powrotu do życia, ponieważ w dziele sztuki zawarte jest w tajemniczy sposób całe życie, wraz z jego - jak pisał Kandyński - „licznymi udrękami, zwątpieniami, chwilami zachwytów i światłem" ${ }^{\prime 34}$. Natomiast o muzyce Arnolda Schönberga Kandyński stwierdzał, „,...) że wprowadza nas [ona] w zupełnie inny świat, gdzie przeżycia muzyczne nie są natury akustycznej, lecz czysto duchowej" ${ }^{35}$. Pod tym, co widoczne i uchwytne - powie również Kandyński - kryje się to, co niewidoczne i nieuchwytne ${ }^{36}$. To oznacza, że sztuka nie mieści się w kategoriach przedstawienia i reprezentacji, lecz daje możliwość otwarcia i zagłębienia się w rzeczywistość, by móc przeżywać jej wewnętrzne pulsowanie.

Kandyński, odróżniając zewnętrzną formę od wewnętrznej treści dzieła sztuki, czyli to, co widzialne, od tego, co niewidzialne, ale mimo to w pewien sposób odczuwalne, pisał w 1926 roku następująco:

Z mojego punktu widzenia można by odróżnić element od „elementu”, przy czym przez "element” powinno się rozumieć samą formę pozbawioną napięć, a przez element - napięcia istniejące wewnątrz formy. Tak więc elementy są abstrakcyjne $\mathrm{w}$ prawdziwym sensie tego słowa, natomiast forma jest ",abstrakcyjna" ${ }^{\prime \prime 2}$.

31 Kandyński, Punkt i linia a płaszczyzna, 64. Por. analizę duchowości obrazów Cézanne'a; Kandyński, O duchowości w sztuce, 50.

32 Por. Kandyński, Punkt i linia a płaszczyzna, 49.

33 Por. tamże, 144-145; Kandyński, Eseje o sztuce i artystach, 104. O tzw. wewnętrznym zwrocie do życia duchowego por. tamże, 125.

${ }^{34}$ Kandyński, $O$ duchowości w sztuce, 26. Por. uwagi o impresjonizmie Claude'a Debussy'ego; tamże, 47. Por. także tamże, 123.

35 Tamże, 48-49. Por. Peter Selz, „The Aesthetic Theories of Wassily Kandinsky and Their Relationship to the Origin of Non-Objective Painting", The Art Bulletin 39 (2) (1957): 132-133.

${ }_{36}$ Por. Kandyński, Punkt i linia a płaszczyzna, 24; Kandyński, O duchowości w sztuce, 67.

${ }^{37}$ Kandyński, Punkt i linia a płaszczyzna, 34. Por. Henry, Voir l'invisible, 65-67. 
Zauważmy, że już 14 lat wcześniej Kandyński twierdził, że sztuka jest bezpośrednim i abstrakcyjnym na nas oddziaływaniem ${ }^{38}$, dlatego urzeczywistnieniem malarskiej treści obrazu nie są zewnętrzne formy, lecz zawarte $w$ tych formach wewnętrzne siły, dynamika i napięcia ${ }^{39}$. Podkreślmy jednak, że to właśnie życie pozwala oddziaływać owym siłom i wyrażać wewnętrzną treść elementów dzieła ${ }^{40}$. Celem badań teoretycznych ma być z kolei rozpoznanie elementów tego życia, uczynienie dostrzegalnym jego pulsowania oraz uchwycenie jego prawidłowości. Filozofia ma natomiast wyciągnąć z tego materiału ostateczne wnioski, a praca badawcza na tym etapie - w najwyższym stopniu syntetyczna ma doprowadzić do prawdziwie wewnętrznych objawieńn ${ }^{41}$. Agnieszka Rejniak-Majewska słusznie jednak zaznacza:

Potrzeba jasnych uporządkowań, dążenie do obiektywizacji i usystematyzowania reguł nie umniejsza roli subiektywnego, wewnętrznego przeżycia. Przeciwnie, to ono pozostaje podstawową miarą w sferze jakościowych zróżnicowań, percepcji i odczuć, będących materią sztuki ${ }^{42}$.

Głos Kandyńskiego w dyskusjach na temat formy (zewnętrza) i treści (wnętrza) w sztuce był niezwykle ważny, a jego stanowisko w tej kwestii nie uległo właściwie żadnym znaczącym modyfikacjom na przestrzeni całej jego pracy teoretycznej. Forma jest zewnętrznym wyrazem wewnętrznej treści dzieła i nie można z niej czynić bóstwa, ponieważ stanowi ona jedynie środek $\mathrm{w}$ wyrażaniu wewnętrznego brzmienia (Klang) pulsującego życia. Brzmienie (Klang) jest duszą formy i dzięki niemu dzieło może ożyć i działać od wewnątrz na zewnątrz. Dla Kandyńskiego to nie forma (materia) jest najważniejsza, lecz treść (duch). To oznacza, że nie ma jednego typu formy - naturalistycznej, realistycznej, , abstrakcyjnej” - która byłaby najlepsza, a przez to zniwelowaniu ulega również spór pomiędzy „-izmami” w sztuce. Dwoma skrajnymi biegunami w sztuce są wielka abstrakcja i wielka realistyka, lecz bieguny te otwierają wiele dróg, które wiodą ostatecznie do jednego celu, dlatego Kandyński w zagadnieniu formy stawia znak równości pomiędzy abstrakcją i realizmem. Stwierdza zwięźle i dobitnie, że problem formy w sztuce w zasadzie nie istnieje. Dowodem na to jest choćby fakt, że gdyby istniał taki problem, to możliwe byłoby także jego rozwiązanie. A gdyby każdy znał odpowiedź na pytanie, jak tworzyć dzieła sztuki, to sztuka w tym momencie przestałaby istnieć. Zasady teoretyczne nie prowadzą wprost do dzieła sztuki,

\footnotetext{
${ }^{38}$ Por. Kandyński, O duchowości w sztuce, 114.

${ }_{39}$ Por. Kandyński, Punkt i linia a płaszczyzna, 33.

40 Por. tamże, 97.

${ }^{41}$ Por. tamże, 158.

${ }^{42}$ Rejniak-Majewska, Chaosmos, 201.
} 
dlatego ktoś, kto znałby te przypuszczalne i jedynie tymczasowe reguły, nie mógłby mieć nigdy pewności, że potrafi stworzyć arcydzieło. W tworzeniu formy nie liczą się prawa teoretyczne, lecz to, czy wyrosła ona z zasady wewnętrznej konieczności ${ }^{43}$. Należy dodać, że zewnętrze (materialna forma) i wnętrze (treść, duch) w dziele sztuki nie są sobie przeciwstawne, lecz wzajemnie dla siebie pracują, dlatego dzieło jest niepodzielnym stopem elementu zewnętrznego i wewnętrznego formy i treści. O wartości, czy też o pięknie dzieła sztuki, decyduje ostatecznie element wewnętrzny, czyli treść, pod warunkiem że forma zewnętrzna jest odpowiednim materialnym wyrażeniem tej treści duchowej, a to z kolei oznacza, że piękno wynika z prawidłowego połączenia elementu wewnętrznego i zewnętrznego ${ }^{44}$.

Kandyński wielokrotnie zwracał uwagę na związek sztuki i życia, a także na wzbogacenie duszy człowieka poprzez kontakt z wewnętrznym pulsowaniem dzieł artystycznych ${ }^{45}$. Wychowanie duszy poprzez sztukę nie polega jednak na wciskaniu $\mathrm{w}$ dzieło jakiejś ideologii lub na artystycznym przyozdabianiu dowolnie wymyślonych treści, ponieważ powstanie i działanie prawdziwego dzieła sztuki owiane jest tajemnicą i jałowe byłoby wspomaganie go wysiłkami umysłowymi lub teoretycznymi uzasadnieniami. Prawdziwym pięknem w dziele sztuki nie jest piękno formalne, albo zawarta w nim moralność powszechnie obowiązująca, ale wszystko to, co nawet w nieuchwytnej formie duszę uszlachetnia i co wynika z wewnętrznej, duchowej konieczności ${ }^{46}$.

Określenie sztuki abstrakcyjnej jako oderwanej od życia okazuje się zatem daleko mylące. W XIX wieku określano ją jako "absolutną" i tak też zresztą robił Kandyński u początków swojej pracy teoretycznej, po czym - przez krótki okres - rozważał zastąpienie pojęcia „sztuka abstrakcyjna/absolutna” pojęciem „sztuka realna”. Miało ono oznaczać, że obok świata zewnętrznego może powstać zupełnie nowy świat natury duchowej, który istnieje realnie wyłącznie dzięki sztuce ${ }^{47}$. Ostatecznie jednak Kandyński uznał - pod koniec lat trzydziestych XX wieku - że najodpowiedniejsze określenie to „sztuka konkretna”. Jest niezwykle istotne, że ten świat sztuki konkretnej, niemający nic wspólnego z potocznie rozumianą rzeczywistościa, czy też inaczej mówiąc - ze światem natury (przyrody), wewnętrznie podlega tym

43 Por. Kandyński, Eseje o sztuce i artystach, 14-23.

${ }^{44}$ Por. tamże, 40; Kandyński, O duchowości w sztuce, 126.

45 Por. Kandyński, Eseje o sztuce i artystach, 70, 126.

46 Por. Kandyński, O duchowości w sztuce, 126, przypis dolny; por. także tamże, 127. Por. uwagi Kandyńskiego na temat przesuwającego się "trójkąta" naprzód i wzwyż jako schematu życia duchowego; tamże, 28-29, 31-35.

47 Por. Kandyński, Eseje o sztuce i artystach, 119. 
samym prawom świata kosmicznego ${ }^{48}$. Kandyński napisze: „I tak obok »świata natury « powstaje nowy świat, tak samo realny i równie konkretny - »świat sztuki «"49. Co więcej, każde dzieło sztuki przedstawia nowy, własny świat, powiadając sobą: „Oto jestem" ${ }^{50}$.

Przed przejściem do analizy poglądów Michela Henry'ego na temat sztuki warto przywołać jeszcze jedną wypowiedź, którą Kandyński podawał jako przykład niedopuszczalnego sposobu uzasadniania bezduszności i bezbożności. Kandyński przytacza następujące słowa niemieckiego patologa Rudolfa Virchowa: „Przeprowadziłem sekcje wielu zwłok i nigdy nie odkryłem w nich śladu jakiejkolwiek duszy" $^{\prime 51}$. To stwierdzenie znajdzie szczególnie bliski odpowiednik w fenomenologii życia Henry'ego: „Nikt nigdy nie widział życia i nikt go nigdy nie zobaczy. Życie jest wymiarem radykalnej immanencji"52. Według Henry'ego także współcześni biologowie przyznają że nie badają już życia, lecz tylko materialne cząsteczki ${ }^{53}$. To sprowadzanie transcendentalnego życia oraz immanentnej ludzkiej rzeczywistości do neuronów i genetyki uważa on wręcz za praktykę bliską nazistowskim lekarzom ${ }^{54}$. Niestety, stwierdza Henry, wszystkie rodzaje wiedzy powstałe z najbardziej źródłowego doświadczenia samoobjawienia transcendentalnego Życia - takie jak religia, etyka i estetyka - są obecnie uważane za przestarzałe i nie mają prawa głosu w konkurencji z „obiektywnymi” naukami ścisłymi i empirycznymi5 ${ }^{55}$. Co więcej, również filozofia, która neguje pojęcie „wewnętrzności”, nie odpowiada na najważniejsze pytania dotyczące rzeczywistości Życia w jego fenomenologicznej materii. Życie transcendentalne, czyli jedyne rzeczywiste życie, jakie „,jest”, Henry określa jako afektywne doznanie (namiętność, pasja, passion) ${ }^{56}$, co wywodzi ze źródłowego pojęcia

48 Do zagadnienia praw kosmicznych powrócimy jeszcze później.

49 Kandyński, Eseje o sztuce i artystach, 140.

50 Tamże, 139. Jest znamienne, że w jednym z ostatnich swoich tekstów Kandyński nawiązuje do przypisu zamieszczonego w rozprawie $O$ duchowości w sztuce, co świadczy o pełnej dojrzałości i ciągłości jego poglądów w całym okresie publikacji prac teoretycznych.

${ }^{51}$ Kandyński, O duchowości w sztuce, 37-38.

52 Henry, O fenomenologii, 79. Por. także tamże, 235.

53 Por. Henry, "Sztuka i fenomenologia życia”: 169.

54 Por. Michel Henry, Wcielenie. Filozofia ciała, przeł. Małgorzata Frankiewicz, Dariusz Adamski (Kraków: Tyniec. Wydawnictwo Benedyktynów, 2012), 317, 441.

55 Por. tamże, 386, 422; Henry, La barbarie, 100, 152.

56 Por. Henry, O fenomenologii, 194; Michel Henry, "Videre videor", przeł. Maja Chmura, przekład przejrzał i poprawił Jacek Migasiński, Przeglad Filozoficzno-Literacki 34 (2012): 57, 65. 
cogitatio Descartesa z dwóch pierwszych Medytacji o filozofii pierwszej $j^{57}$ oraz fragmentów Namiętności duszy - zwłaszcza artykułu XXVI ${ }^{58}$.

\section{Niewidzialna szłuka objawiająca Życie (Henry)}

Dan Zahavi całe dzieło Michela Henry'ego określa jako ambitną próbę rozwinięcia fenomenologii niewidzialnego i od razu odżegnuje krytykę skierowaną przeciw niemu za niepotrzebne używanie paradoksalnej terminologii ${ }^{59}$. W wykładni Henry'ego Życie - rozumiane jako materia fenomenologiczna, a nie życie biologiczne ${ }^{60}$ - jest źródłem i ostateczną zasadą wszystkiego, co w jakikolwiek sposób może być dane człowiekowi w przeżyciu (doznaniu, doświadczeniu) ${ }^{61}$. Według Henry’ego życie poprzedza wszelkie inne kategorie filozoficzne, takie jak bycie czy czas, dlatego ilekroć w rozważaniach o sztuce Henry odwołuje się do kategorii życia, należy mieć w pamięci to fundamentalne znaczenie, na którym opiera się cały jego projekt fenomenologiczny ${ }^{62}$.

57 Por. René Descartes, Medytacje o pierwszej filozofii, przeł. Maria i Kazimierz Ajdukiewiczowie (Kęty: Wydawnictwo ANTYK, 2001), 42-56. Por. Henry, La barbarie, 27-34.

58 Por. René Descartes, Namiętności duszy, przeł. Ludwik Chmaj (Kęty: Wydawnictwo ANTYK, 2001), 40. Por. także Michel Henry, „Fenomenologia nie-intencjonalna: zadanie fenomenologii przyszłości", przeł. Jacek Migasiński, w: Fenomenologia francuska. Rozpoznania, interpretacje, rozwinięcia, red. Iwona Lorenc, Jacek Migasiński (Warszawa: IFiS PAN, 2006), 433; Henry, „Sztuka i fenomenologia życia”: 169; Henry, O fenomenologii, 189; Paul Gilbert, „Michel Henry i immanencja”, przeł. Robert Grzywacz, w: Michel Henry - fenomenolog życia, red. Andrzej Gielarowski, Robert Grzywacz (Kraków: Wyższa Szkoła Filozoficzno-Pedagogiczna „Ignatianum”, Wydawnictwo WAM, 2010), 116-117. Na temat wątków kartezjańskich w fenomenologii Henry'ego por. Jacek Migasiński, „Kartezjusz podług Henry’ego: początek fenomenologii”, Przeglad Filozoficzno-Literacki 34 (2012): 207-209, 214-217; Wojciech Starzyński, Neokartezjanizm fenomenologii francuskiej (Warszawa: IFiS PAN, 2014), 227-253; Sabina Kruszyńska, „Ugruntowanie podmiotu w fenomenologii radykalnej Michela Henry'ego", Miscellanea Anthropologica et Sociologica 17 (2016): 77-79.

59 Por. Dan Zahavi, „Michel Henry i fenomenologia niewidzialnego", przeł. Paulina Sosnowska, Przeglad Filozoficzno-Literacki 34 (2012): 325.

${ }^{60}$ Por. Henry, La barbarie, 224; Henry, O fenomenologii, 97, 158.

${ }^{61}$ Por. Michel Henry, Słowa Chrystusa, przeł. Kazimierz Mrówka (Tarnów: Wydawnictwo Diecezji Tarnowskiej Biblos, 2012), 100; Marek Drwięga, „Cielesność i Życie, czyli o filozofii Michela Henry'ego", w: Michel Henry, Wcielenie. Filozofia ciała, przeł. Małgorzata Frankiewicz, Dariusz Adamski (Kraków: Tyniec. Wydawnictwo Benedyktynów, 2012), 16; Migasiński, „Kartezjusz podług Henry’ego”: 211.

${ }_{62} \mathrm{Na}$ gruncie polskiej literatury filozoficznej fenomenologia sztuki Michela Henry'ego w perspektywie kategorii życia została już rozpoznana - por. Andrzej Gielarowski, Kryzys kultury, kryzys człowieka (Kraków: Wydawnictwo WAM, 2016), 275-401; Sabina Kruszyńska, Kulturalny barbarzyńca. Fenomenologia radykalna Michela Henry'ego jako filozofia sztuki życia (Kraków: TAiWPN Universitas, 2018); Murawska, 
W rozprawie Voir l'invisible przeczytamy następujące stwierdzenie:

Tematem początkowym sztuki, jej prawdziwym obiektem zainteresowania jest życie. U swego źródła każda sztuka jest święta, jej jedyną troską jest to, co nadprzyrodzone. To znaczy ściśle, że zajmuje się życiem - nie tym widzialnym, ale niewidzialnym ${ }^{63}$.

Według Henry'ego cała substancja dzieła sztuki pochodzi z życia i tylko z niego. To pochodzenie nie prowadzi jednak do artystycznego przeniesienia pierwotnego Niewidzialnego (wnętrza) na zewnętrze (dzieło sztuki), gdzie pozwalałoby się zobaczyć, lecz przeciwnie, związek ten oznacza:

(...) utrzymanie go w jego własnym miejscu, w nieuprzedmiotawiającej i nieprzedstawiającej podmiotowości, która prowadzi jedynie do bardziej żywych, bardziej intensywnych doświadczeń ${ }^{64}$.

Rzeczywistość życia, jego doznaniowa i niewidzialna cielesność, nigdy nie pokazuje się w świecie, a jedynie samoobjawia żyjącej Sobości $(S o i)^{65}$. Nie ma też żadnego dostępu do Życia, które opierałoby się poza nim samym, czyli na czymś zewnętrznym i różnym od niego samego. Jedyny dostęp do Życia mamy poprzez samych siebie, gdzie buduje się wszelka pojmowalna Sobość - nie sobość anonimowa, lecz Sobość poszczególna, czyli jako absolutne i zarazem subiektywne ja. Życie poprzedza każdą Sobość i zradzając ją, samo przychodzi w siebie, a żyjący przychodzą do Życia ${ }^{66}$. Przytoczmy ważną wypowiedź Henry'ego:

Ja sam jestem tą niepowtarzalną Sobością, zrodzoną w samorodzeniu się absolutnego życia i jestem tylko tym. Życie samo rodzi siebie jako mnie. Moje transcendentalne narodziny to powstawanie w samorodzeniu się absolutnego życia niepowtarzalnej Sobości, którą ja sam jestem ${ }^{67}$.

„Filozofia źródłowa »contra« antropologia”, 123-146 - dlatego opracowania tego tematu zostaną tutaj uzupełnione przede wszystkim pracami rzadko dotąd przywoływanymi. Dodajmy, że fenomenologią życia Michela Henry'ego w szerszym kontekście, a nie tylko $\mathrm{w}$ odniesieniu do sztuki, zajmuje się $\mathrm{w}$ Polsce wielu wybitnych naukowców, do których w dalszej części artykułu również będę się odwoływał.

${ }^{63}$ Michel Henry, „Zobaczyć niewidzialne. O Kandinskym”, przeł. Dorota Molińska, Artium Quaestationes 22 (2011): 352.

${ }^{64}$ Tamże, 360. Por. Yampolskaya, „Metamorphoses”: 159.

65 Por. Henry, Wcielenie, 159; Henry, Stowa Chrystusa, 36-38.

${ }_{66}$ Por. Henry, Stowa Chrystusa, 161-162, 173.

${ }^{67}$ Henry, O fenomenologii, 176. O różnicy pomiędzy narodzinami a przyjściem na świat por. także tamże, 166, 169, 181. Do tego wątku za chwilę jeszcze powrócimy. 
Wielokrotnie zwracano uwagę i podkreślano, że Henry dokonuje odwrócenia fenomenologii, przeciwstawiając intencjonalności i ek-statycznemu jawieniu się świata bardziej źródłowy modus przejawiania się. Tym modusem jest immanentne samoobjawienie życia $\mathrm{w}$ jego niewidzialnym patosie (doznaniu, pathos), a przez to fenomenologii życia zostaje wyznaczony zupełnie nowy obszar badań ${ }^{68}$. Chodzi nie tylko o przebadanie tego, co niewidzialne, tj. niepokazujące się $\mathrm{w}$ świecie, a tylko w życiu, które determinuje nasze głębokie życie duchowe, ale również, jak mówi Henry, „(...) o uczynienie inteligibilnym stosunku, jaki utrzymują między sobą obydwa decydujące modusy, według których fenomenalność się fenomenalizuje: widzialny i niewidzialny"69. Sposób fenomenalizacji życia różni się fundamentalnie od sposobu fenomenalizacji świata, dlatego aby uniknąć ekwiwokacji, ten pierwszy Henry nazywa objawieniem ${ }^{70}$. Mówiąc zwięźle, życie objawia się, a nie ukazuje, przy czym należy pamiętać, że niewidzialne objawienie życia poprzedza wszelkie pojmowalne i ukazujące się w świecie widzialne ${ }^{71}$. Odwrócenie fenomenologii zaznacza się również w tym, że to nie myśl daje dostęp do życia, lecz życie pozwala dojść myśli do siebie ${ }^{72}$. Dlatego też cogitatio złudnie może oznaczać zarówno intencjonalne widzenie, jak $\mathrm{i}$ „patetyczne samodawanie się w absolutnym Życiu”73. Tu widać również, że Życie to Arcy-inteligibilność, w której Życie samoobjawia się sobie, a dzięki temu objawia się każdej zrodzonej przez siebie żyjącej Sobości. Objawienie oznacza tu jawienie się poza intencjonalnościa, czyli jawienie $\mathrm{w}$ źródłowym, nieintencjonalnym i nieekstatycznym modusie fenomenalizacji w czystej materii fenomenologicznej ${ }^{74}$. A to z kolei ozna-

68 Por. Henry, Słowa Chrystusa, 168, 295; Henry, „Fenomenologia nie-intencjonalna”, 418-419, 429-432, 437. Por. także Monika Murawska, "Samo źródło źródłowości. Kategoria jawienia się w fenomenologii Michela Henry'ego i Henri Maldineya", Przeglad Filozoficzno-Literacki 34 (2012): 297. O tzw. monizmie ontologicznym por. Zahavi, „Michel Henry i fenomenologia niewidzialnego": 319-321; Henry, O fenomenologii, 94-96, 98, 108.

${ }^{69}$ Henry, Wcielenie, 168. O dwóch modusach jawienia się (fenomenalizacji) w modusie świata i życia - por. także tamże, 175-178; Michel Henry, „Przedmowa do wydania włoskiego Genealogii psychoanalizy", przeł. Paweł Orłowski, Przeglad Filozoficzno-Literacki 34 (2012): 22-24. Por. także Monika Murawska, „Post-fenomenologia jako źródło cierpień”, Przegląd Filozoficzno-Literacki 34 (2012): 11; Yampolskaya, „Metamorphoses": 158 .

70 Por. Henry, O fenomenologii, 213, 248; Henry, "Sztuka i fenomenologia życia”: 162.

71 Por. Henry, Wcielenie, 172.

72 Por. tamże, 291.

73 Tamże, 169.

${ }^{74}$ Por. tamże, 166; Henry, O fenomenologii, 97, 163. Por. także Monika Murawska, „Piękno nieintencjonalne. Fenomenologia sztuki Michela Henry'ego”, w: Między przedmiotowościa a podmiotowościa: intencjonalność w fenomenologii francuskiej, red. Andrzej Gielarowski, Robert Grzywacz (Kraków: Akademia Ignatianum, Wydawnictwo 
cza, że nie jest możliwe noetyczno-noematyczne oglądanie w adekwatnej wizji (naoczności) tego, czym życie „jest" w swej istocie ${ }^{75}$.

Jak więc można doświadczyć niewidzialnego życia dzięki sztuce? Podobnie jak to miało miejsce u Kandyńskiego, dla Henry'ego widzieć według zasad abstrakcji znaczy doświadczać „patosu” tego, co dane, a przez to - "być rzeczywistością tego patosu, być Życiem"77. W ten sposób abstrakcyjną treścią każdego dzieła sztuki jest życie ${ }^{77}$. Dodajmy, że „zasada wewnętrznej konieczności”, która determinuje dobór środków do osiągnięcia celu artystycznego, również zostaje przez Henry'ego utożsamiona $\mathrm{z}$ życiem ${ }^{78}$. Wewnętrzne życie elementów sztuki staje się identyczne z siłami życia, ale - co niezwykle ważne - nie z nim samym, choć zapewne mamy tu do czynienia z pewną homogenicznością sztuki i życia ${ }^{79}$.

W eseju Kandyńskiego O formie przeczytamy: „Świat dźwięczy (klingt). Jest kosmosem duchowo działających bytów. I tak martwa natura staje się żyjącym duchem" ${ }^{\prime 80}$. To oznacza, że nie należy redukować kosmosu jedynie do cech zewnętrznych, lecz trzeba przywrócić mu dynamiczną, wrażeniową i patetyczną naturę, której istotą jest właśnie Życie, dlatego kosmos zostaje tu ujęty nie tyle jako system zewnętrznie działających sił we wszechświecie, lecz jako żywy, dynamiczny i wrażeniowy organizm duchowy ${ }^{81}$. Malarstwo abstrakcyjne - a więc w zasadzie każde

WAM, 2011), 209-210. Henry'ego rozumienie „objawienia” przywodzi na myśl oczywiście fenomenologię Jeana-Luca Mariona, który określa objawienie jako samowystarczalne, nieuwarunkowane i niehoryzontalne pojawianie się; por. Jean-Luc Marion, „The Saturated Phenomenon”, Philosophy Today 40, 1 (1996): 103-124. Z kolei w Będac danym fenomen objawienia Marion określa jako przesycenie fenomenu przesyconego, stając się przez to fenomenem przesyconym (paradoksem) drugiego stopnia; por. Jean-Luc Marion, Będac danym. Esej z fenomenologii donacji, przeł. Wojciech Starzyński (Warszawa: IFiS PAN, 2007), 284-287. Por. także Jean-Luc Marion, Givenness and Revelation, przeł. Stephen E. Lewis (Oxford-New York: Oxford University Press, 2016), 4-7, 48-60; Jean-Luc Marion, The Visible and the Revealed, przeł. Christina M. Gschwandtner i in. (New York: Fordham University Press, 2008), 13-17, 45-46, 122.

${ }^{75}$ Por. Henry, Wcielenie, 172. Por. także Murawska, „Samo źródło źródłowości”: 302.

${ }^{76}$ Henry, „Zobaczyć niewidzialne”: 357. Por. także Henry, La barbarie, 53.

77 Por. Henry, Voir l'invisible, 123.

78 Por. tamże, 212-214.

79 Por. tamże, 90-93.

${ }^{80}$ Kandyński, Eseje o sztuce i artystach, 25. Por. Henry, "Zobaczyć niewidzialne": 358; Henry, O fenomenologii, 245.

${ }^{81}$ Por. Henry, "Zobaczyć niewidzialne”: 363. Wessel Stoker zwraca uwagę, że fenomenologia Henry'ego jest zorientowana antropologicznie i tak jest zresztą u Kandyńskiego, aczkolwiek filozofia sztuki Kandyńskiego z pewnością posiada wyraźniejsze cechy kosmocentryzmu, co z pewnością nie jest identyczne z poglądami Henry'ego; Wessel. Stoker, Where Heaven and Earth Meet, przeł. Henry Jansen 
dzieło sztuki - odchodzi od zewnętrznej „powłoki” natury (przyrody), ale nie od uniwersalnych praw, które odczuwa się podświadomie i przeżywa wewnętrznie ${ }^{82}$. Co więcej, abstrakcyjność i afektywność sztuki nie tylko nie przeciwstawia się naturze (przyrodzie), ale wręcz odkrywa jej prawdziwą wewnętrzną istotę ${ }^{83}$. Henry pyta jednak: „Jak sztuka odróżnia się od tego kosmosu, z którym łączy ją wspólna istota?"84. Odpowiedzi padają dwie: dzięki temu, że sztuka posiada swe własne zasady, oraz przez to, że jest rozwojem kultury.

Kolejną istotną kwestią jest to, dzięki jakiej władzy możemy doświadczać niewidzialnego życia. Tu Henry dokonuje analizy afektywności transcendentalnej, będącej warunkiem możliwości radykalnej wewnętrzności każdej możliwej zewnętrzności, ponieważ to właśnie niewidzialna immanencja poprzedza i warunkuje każdą widzialną transcendencję. Afektywność transcendentalną należy rozumieć nie jako zespół władz zmysłowych, dzięki którym możemy doświadczać świata, lecz jako możność doznawania rzeczywistego i niewidzialnego życia ${ }^{85}$. Tę źródłową transcendentalną afektywność Henry nazywa również doznaniem (pathos) ${ }^{86}$, a afektywne doznawanie Życia stanowi fenomenologiczną immanentną rzeczywistość (materię) żyjącej Sobości ${ }^{87}$. Doświadczanie (doznawanie, pathos) sztuki, a także życia oraz samego siebie wraz ze wszystkimi wrażeniami (impresjami), które pochodzą z dwóch źródłowych i fundamentalnych fenomenologicznych nastrojów cierpienia i rozkoszowania sięer, nigdy nie znajduje się po stronie przedmiotu (zewnętrza), który jest martwy i z zasady niezdolny do jakiegokolwiek odczuwania, ale po stronie samowrażającej się afektywności w obrębie

(Amsterdam-New York: Editions Rodopi B.V., 2012), 84-85. Transcendentalne Życie u Henry'ego jest a-kosmiczne w tym sensie, że nie można go badać w sposób, jaki obowiązuje w naukach od czasu projektu Galileusza, co nie podważa jednak uznania przez Henry'ego sposobu traktowania kosmosu jako duchowego organizmu.

82 Por. Kandyński, Eseje o sztuce i artystach, 133, 151.

83 Por. Henry, "Zobaczyć niewidzialne": 365; Henry, O fenomenologii, 158-159.

${ }^{84}$ Henry, "Zobaczyć niewidzialne": 363.

85 Por. Henry, Wcielenie, 328-329.

86 Por. Henry, O fenomenologii, 193.

87 Por. tamże, 258. Na marginesie odnotujmy, że choć Kandyński mówił najczęściej o duchowości w sztuce, rozumianej jako immanentny, immaterialny i wrażeniowy wymiar dzieła, to posługiwał się także wyrażeniem „wewnętrzne życie”. Z kolei takie terminy jak "siła” oraz „napięcie”, które tak często spotykamy w jego pracach, dobrze oddają dynamiczny charakter procesów afektywnych w doświadczaniu sztuki zakorzenionej $\mathrm{w}$ transcendentalnym Życiu. Poza tym zauważmy jeszcze, że we Wcieleniu Henry utożsamia ducha i życie: „(...) duch, co nie jest niczym innym jak życiem (...)"; Henry, Wcielenie, 377.

88 Por. Henry, O fenomenologii, 106-107, 185, 192-193, 196-197; Henry, La barbarie, 68-69. 
immanencji każdej poszczególnej Sobości ${ }^{89}$. I tak świat sztuki, czy też świat dzieła, nie jest obiektem zewnętrznym, ponieważ jego jedyną rzeczywistą treścią jest niewidzialne życie w immanencji doznającej Sobości. Henry zadaje również pytanie: jeśli treścią sztuki jest życie, to jakim dobrem jest sama sztuka, skoro życie jest przed nią i bez niej? Według niego Życie daje sztukę, a sztuka jest modusem tego Życia, będąc sposobem jego samo-doznawania (auto-affection) ${ }^{90}$. Dlatego też Henry stwierdzi: „Sztuka jest zmartwychwstaniem wiecznego życia”"91.

W fenomenologii Henry'ego sztuka urasta do rangi najwyższej aktywności, ponieważ zarówno w cierpieniu, jak i w rozkoszowaniu się życiem, czyli w doznaniowości dwóch podstawowych modusów afektywności transcendentalnej, życie każdego subiektywnego ja „przychodzi do samego siebie ${ }^{\prime \prime 2}$. Sztuka dąży do wyrażenia tej abstrakcyjnej treści, jaką jest nasza radykalna subiektywność w niewidzialnym życiu ${ }^{93}$. Choć upraszczające schematy bywają niekiedy bardziej zaciemniające niż rozjaśniające problemy filozoficzne, to Henry nie waha się postawić znaku równości pomiędzy takimi terminami, jak: „wewnętrzny”, „wewnętrzność”, „niewidzialne”, „życie”, „doznaniowość” (pathos), „abstrakcja”"94.

Przytoczmy obszerniejszy cytat z Wcielenia, aby móc potem jeszcze raz odnieść się do zagadnienia objawiania się życia w sztuce:

Otóż życie doznaje siebie w patosie; to źródłowa i czysta Afektywność, ta Afektywność, którą nazywamy transcendentalna, ponieważ to ona zaiste umożliwia doznawanie samego siebie bez dystansu, w nieubłaganym procesie doświadczania i $\mathrm{w}$ nieprzezwyciężonej pasywności jakiejkolwiek pasji. To w tej Afektywności i jako Afektywność dokonuje się samoobjawienie życia. Źródłowa Afektywność jest fenomenologiczna materia samoobjawiania, które konstytuuje istotę życia. Tę to materię życie czyni materią wrażeniową, co nigdy nie jest materią bezwładna, martwą tożsamością

${ }^{89}$ Por. Henry, Voir l'invisible, 124-125. „Samowrażanie” w języku polskim brzmi dość niejasno, lecz kolejny cytowany w tekście głównym fragment z Wcielenia przybliży znaczenie tego wyrażenia poprzez terminy "samowrażalność" i „samowrażanie". Zaznaczmy tutaj jedynie, że Życie samo siebie „wraża” w Sobość, a doznająca („patetyczna”) Sobość doświadcza tej „wrażeniowości” Życia, stąd w tej kolistości dochodzi do samowrażania się afektywności transcendentalnej, będącej żywiołem Życia.

90 Por. tamże, 207-210.

${ }^{91}$ Henry, „Zobaczyć niewidzialne”: 367. Por. także Henry, „Sztuka i fenomenologia życia": 173.

92 Por. Henry'ego uwagi, dotyczące radykalnej pasywności doświadczania samego siebie w immanencji doznaniowej samoafektywności w relacji do absolutnego życia; Henry, O fenomenologii, 105, 186-187, 194-195; Henry, La barbarie, 126-128.

93 Por. Henry, Voir l'invisible, 42.

${ }^{4}$ Por. tamże, 25. Por. także Murawska, „Sztuka, która pozwala zobaczyć niewidzialne": 146. 
jakiejkolwiek rzeczy. To wrażeniowa materia, która wrażeniowo doznaje samej siebie i nie przestaje tego czynić, to żyjąca samowrażalność, samowrażeniowość. Ta żyjąca samowrażalność to pojedyncza cielesnośćc5.

Wcześniej zostało już zasygnalizowane, że „miejscem” dostępu do niewidzialnego życia jest czysta, absolutna podmiotowość, a więc każda poszczególna Sobość, a dostęp do życia uzyskujemy, żyjąc - doświadczając życia i samego siebie. To doświadczenie nie otwiera nas na zewnętrzność i odmienność, lecz jest skierowane na siebie samo, stąd właściwością życia jest samo-doznaniowość (auto-affection) i samowrażalność (auto-impression) ${ }^{96}$. Życie, doznając siebie, jest jednocześnie tym, co pobudza, jak i tym, co jest pobudzane, a można je uchwycić poprzez takie modalności życia, jak: radość, lęk, siła, zmęczenie, przyjemność, ból, cierpienie czy rozkosz ${ }^{97}$. Afektywny charakter wrażenia odsyła do najbardziej wewnętrznego i patetycznego samoobjawienia się cielesności (la chair) w życiu ${ }^{98}$. Tu dochodzimy do ważnego rozróżnienia pomiędzy ciałem (le corps) a cielesnością (la chair) ${ }^{99}$. Dzieło sztuki w potocznym rozumieniu, jako fizyczny przedmiot, jest martwym ciałem (le corps), podczas gdy cała jego warstwa wrażeniowa to cielesność (la chair) ${ }^{100}$. Żywa cielesność, w której objawia się życie, różni się radykalnie od ciała i materii świata ${ }^{101}$, dlatego, twierdzi Henry, „, ...) żadna cielesność nie jest zdolna jawić się w jawieniu świata"102. To oznacza, że prawdziwa natura i istota sztuki, objawiająca się we wrażeniowej cielesności

95 Henry, Wcielenie, 122-123. Por. także Henry, "Sztuka i fenomenologia życia": 178; Henry, O fenomenologii, 220-221; Jean Leclercq, "Droga ku słowom Boga. Michel Henry i nauka chrześcijańska”, przeł. Monika Murawska, Przeglad Filozoficzno-Literacki 34 (2012): 382-383.

96 Por. Henry, O fenomenologii, 80-82. Por. także Drwięga, "Cielesność i Życie”, 20-21.

97 Por. Drwięga, „Cielesność i Życie”, 21; Jean-François Petit, „Michel Henry: intencjonalność między marksizmem a chrześcijaństwem", przeł. M. Murawska, w: Między przedmiotowościa a podmiotowościa: intencjonalność w fenomenologii francuskiej, red. Andrzej Gielarowski, Robert Grzywacz (Kraków: Akademia Ignatianum, Wydawnictwo WAM, 2011), 375-376.

98 Przypomnijmy, że wrażeniowość oznacza tu samowrażalność, czyli oddziaływanie na samo siebie w obrębie immanencji, a także podkreślmy, że samowrażeniowość jest samoobjawieniem życia w poszczególnej Sobości; por. Henry, Wcielenie, 122, 219. Zwróćmy także uwagę na to, że Henry uznaje termin Klang („,wewnętrzne brzmienie”) za odpowiednik „wrażliwości życia”; por. Henry, „Przedmowa do wydania włoskiego Genealogii psychoanalizy": 23-24.

99 Por. Monika Murawska, „Meandry cielesności. Różne oblicza fenomenologii ciała”, w: Wprowadzenie do fenomenologii. Interpretacje, zastosowania, problemy, t. 1, red. Witold Płotka (Warszawa: Wydawnictwo IFiS PAN, 2014), 469-472.

${ }_{100}$ Por. Henry, Wcielenie, 31-32.

101 Por. tamże, 54.

102 Tamże, 86. 
doznającej Sobości dzięki Życiu, jest niewidzialna. Uściślijmy, że nie tylko żyjąca rzeczywistość sztuki jest niewidzialna, ale cielesność człowieka również ${ }^{103}$. Związek cielesności z Życiem został przez Henry'ego precyzyjnie ustalony: „Cielesność to właśnie sposób, w jaki życie staje się Życiem. Nie ma Życia bez jakiejś cielesności, ale i nie ma cielesności bez Życia"104. Nie ma także cielesności, która nie niosłaby konkretnej Sobości, która byłaby cielesnością niczyja, anonimową, bezosobową i nieodczuwającą Życia ${ }^{105}$. Przyjść w życie jako Sobość transcendentalna $\mathrm{w}$ pojedynczej cielesności oznacza narodzić się - w przeciwieństwie do przyjścia na świat jako ciało-przedmiot ${ }^{106}$. W świecie, $\mathrm{w}$ którym są tylko ciała, a żadnej cielesności, nie może być mowy o narodzinach, ponieważ tylko w życiu możliwa jest cielesność, której rzeczywistością jest wrażeniowa i patetyczna, fenomenologiczna materia Życia ${ }^{107}$.

W swoich analizach Henry nawiązuje do istotnego rozróżnienia Edmunda Husserla na barwę noematyczną (noematische Farbe) i wrażeniową (Empfindugsfarbe), gdzie ta pierwsza jest barwą widzialną i uchwyconą na przedmiocie, a druga jest przeżywana i niewidzialna. Nietrudno jest się domyślić, że barwie wrażeniowej (doznaniowej, immanentnej) Henry przypisuje rzeczywistość, której jedynie intencjonalną projekcją jest barwa widziana (noematyczna) ${ }^{108}$. W innym miejscu natomiast przeczytamy:

Nie ma czerwieni w świecie. Czerwień jest doznaniem i to doznanie okazuje się absolutnie subiektywne, źródłowo niewidzialne. Źródłowe kolory są niewidzialne, ale rozpościerają się na rzeczach dzięki procesowi projekcji $^{109}$.

To źródłowe, immanentne wrażenie nie może zostać sprowadzone do jakości zewnętrznej przedmiotu, ponieważ wewnętrzne doznanie "wydane na pastwę jawienia się świata" zostałoby po prostu zniszczone, jako że żaden przedmiot nie jest zdolny do posiadania jakiejkolwiek wrażeniowości ${ }^{110}$. I w tej źródłowej, wrażeniowej, immanentnej

${ }^{103}$ Por. tamże, 54, 274, 347-348, 397; Henry, O fenomenologii, 193; Henry, Stowa Chrystusa, 40.

104 Henry, Wcielenie, 221. Por. tamże, 361.

105 Por. tamże, 224-225, 317, 361; Henry, O fenomenologii, 219.

106 Por. Henry, Wcielenie, 225-226; Henry, O fenomenologii, 102.

107 Por. Henry, Wcielenie, 233-234.

108 Por. tamże, 99, 104, 281; Henry, O fenomenologii, 157-158, 160-161. Por. także Pokropski, „Husserl i Henry": 233-234, 242-246.

${ }_{109}$ Henry, „Sztuka i fenomenologia życia”: 163.

110 Por. Henry, Wcielenie, 105. 
doznaniowości objawia się - czy też fenomenalizuje się - Życie, które przychodzi do siebie przed wszelką intencjonalnością i poza światem ${ }^{111}$.

Podkreślmy również, że estetyka stanowi dla Henry'ego formę religii, rozumianą jako więź każdego transcendentalnego bytu żyjącego z Życiem absolutnym ${ }^{112}$. Ponadto sztuka, która budzi afektywne i dynamiczne siły życia, jest ze swej natury etyczna, a doświadczenie estetyczne okazuje się ostatecznie święte, czego implikacją jest również to, że wszystkie dzieła sztuki są dziełami świętymi ${ }^{113}$. Co więcej, nie tylko „święte" dzieło sztuki, ale nawet najbardziej niepozorne i banalne z wrażeń niesie $\mathrm{w}$ sobie możliwość objawienia Absolutu ${ }^{114}$. W tym miejscu Henry kieruje swoją drogę myślową w stronę fenomenologii chrześcijańskiej, teologicznej bądź - jak niekiedy fenomenologia Henry'ego jest określana - chrystologicznej, gdzie samoobjawienie (autodonacja, samodawanie się) Życia byłoby objawianiem się (monstrancją monstration) Boga, narodziny pojedynczej Sobości byłyby zradzaniem się poprzez Słowo Chrystusa w kondycji Syna Boga, a Logos Życia byłby Słowem Boga ${ }^{115}$.

\section{Trudności ontologiczne, pistemologiczne i aksjologiczne}

Obie przedstawione wyżej koncepcje sztuki budzą liczne problemy, wikłając czytelnika niekiedy w niejasnościach lub niedopowiedzeniach. Problemy te można określić jako ontologiczne, epistemologiczne oraz aksjologiczne, chociaż - jak się za chwilę okaże - trudno jest je od siebie wyraźnie oddzielić, ponieważ pozostają ze sobą w ścisłym powiązaniu i nieustannie wzajemnie się przenikają ${ }^{116}$.

Duchowa treść dzieła sztuki zostaje ulokowana nie w zewnętrznym materiale dzieła, lecz w wewnętrznym przeżyciu odbiorcy. Radykalna filozofia immanencji Michela Henry'ego abstrahuje od świata po to, aby we wnętrzu żyjącej Sobości poszukiwać niewidzialnej więzi z Życiem

111 Por. tamże, 114; Henry, O fenomenologii, 99.

112 Por. Henry, „,Sztuka i fenomenologia życia”: 169; Michel Henry, „Etyka i religia w fenomenologii Życia", przeł. Monika Murawska, w: Michel Henry-fenomenolog $\dot{z}$ ycia, red. Andrzej Gielarowski, Robert Grzywacz (Kraków: Wyższa Szkoła Filozoficzno-Pedagogiczna „Ignatianum”, Wydawnictwo WAM, 2010), 150.

113 Por. Henry, „Sztuka i fenomenologia życia”: 169; Henry, La barbarie, 221, 243-244.

114 Por. Henry, Wcielenie, 294. Por. także Marion, The Visible and the Revealed, 125-126.

115 Por. Henry, Wcielenie, 446; Henry, Słowa Chrystusa, 54, 66, 100-101; Henry, O fenomenologii, 183.

116 Oczywiście czwartym wymiarem sztuki o wielkim znaczeniu jest jej aspekt teologiczny, którego tu jednak nie będziemy szeroko analizować. 
transcendentalnym, a odwrócenie fenomenologii polega na prymacie niewidzialnego nad widzialnym, cielesności nad ciałem, afektywności nad zmysłowością wewnętrzności nad zewnętrznością oraz życia nad światem. Jeśli twórczość artystyczną rozumielibyśmy jako tworzenie świata „na zewnątrz”, to prawdziwa rzeczywistość sztuki, czyli jej duchowa treść jako niewidzialne życie, okazuje się całkowicie obca światu „obiektywnemu", ponieważ Życie nie jest tworzone tak jak rzecz, lecz jest procesem wiecznego samozradzania ${ }^{117}$. Dan Zahavi zauważa, że projekt fenomenologiczny Henry'ego może budzić sprzeciw naukowców nie tylko z kręgu tzw. nauk twardych, ale również w kręgach filozoficznych. Czy przeniesienie punktu ciężkości z widzialności ku niewidzialności jest fenomenologicznie uzasadnione? Czy dociekanie owej niewidzialności mieści się jeszcze w obrębie badań fenomenologicznych, czy też może należy je pozostawić myśleniu metafizycznemu i spekulatywnemu? ${ }^{118} \mathrm{Z}$ kolei James Hart wysuwa wątpliwości, czy jest możliwe wskrzeszenie dziedziny immanencji nieintencjonalnego objawiania się Życia bez aktów refleksji, czyli bez aktów intencjonalnych ${ }^{119}$.

Gdy rozważamy możliwość poznania dzieła sztuki, które byłoby zarazem sposobem jego prawdziwego przeżycia $w$ wewnętrznym doznaniu, to mimowolnie nasuwa się przypuszczenie, że twórca zna swoje dzieło lepiej niż jego odbiorcy. Wydawałoby się, że od artysty-twórcy, znającego dobrze swoje rzemiosło, możemy oczekiwać pełnych informacji na temat tego, jakim inspiracjom on podlegał, jak przebiegał proces twórczy dzieła oraz dlaczego zostały zastosowane takie, a nie inne środki artystyczne w procesie powstawania dzieła. Takie przypuszczenie okazuje się jednak - zdaniem Kandyńskiego - złudne. Uwaga artysty koncentruje się całkowicie na formie, dlatego nie tylko nie martwi się on o ostateczny cel dzieła artystycznego, ale wręcz go nie zna. Twórca słyszy jedynie wewnętrzny głos, który podpowiada mu, co jest „dobrze”, a co „źle”, a gdy ten głos intuicji staje się niewyraźny, to powinien odłożyć pracę. Artysta podlega inspiracjom z zewnątrz, by następnie je przetworzyć w swoim wewnętrznym życiu (duszy). Inspiracja nie ogranicza się jednak do jakiejś wybranej części świata, ale do wszystkich najróżniejszych przejawów dynamicznego i duchowego życia kosmosu. To z kolei oznacza, że analiza w sztuce umożliwia poznanie co najwyżej „rzemiosła”, ale nie tej syntetycznej siły, jaką jest inspiracja ${ }^{120}$. Przypomnijmy, że celem nauczania w Bauhausie było przekroczenie granic

117 Por. Henry, Słowa Chrystusa, 112; Henry, O fenomenologii, 88-89, 100, 171; Drwięga, "Cielesność i Życie”, 25.

118 Por. Zahavi, „Michel Henry i fenomenologia niewidzialnego": 330-332.

119 Por. Hart, „Teoria fenomenologiczna i krytyka kultury": 362.

120 Por. Kandyński, Eseje o sztuce i artystach, 110-111, 123-124. 
danej dziedziny artystycznej i dojście do dzieła syntetycznego ${ }^{121}$. Świadome uchwycenie owej syntetyczności dzieła wydaje się jednak niemożliwe, a przez to także odbiór dzieła sztuki nie może być identycznym powtórzeniem „,wibracji”, jakie zachodziły w twórcy podczas pracy nad dziełem. Zasadniczym powodem tej niemożliwości jest to, że - przytaczając słowa Kandyńskiego - „(...) absolutnie dokładne powtórzenie czegokolwiek nie leży w granicach naszych możliwości"122. Tym sposobem eksplikacja - w znaczeniu Husserlowskim - dzieła sztuki nie może spełnić podstawowych kryteriów naukowości, jakimi są powtarzalność doświadczeń oraz ich komunikowalność, a przez to poznanie (episteme) dzieła sztuki staje się niedowodliwe, ponieważ opiera się jedynie na subiektywnych przekonaniach (doksa), niepoddających się obiektywizacji1 ${ }^{123}$. Sam Kandyński uprzedzał swoich czytelników, że jego obserwacje na temat oddziaływania elementów sztuki malarskiej są - jak podaje "(...) rezultatem empiryczno-duchowych wrażeń i nie opierają się na żadnej naukowej wiedzy"124. Według niego nie ma żadnego miernika jakości (wartości) dzieła sztuki - nie tylko dzieła "abstrakcyjnego", ale jakiegokolwiek - a jego stanowisko w kwestii możliwości wartościowania sztuki brzmi krótko: „Nie ma »termometru « do mierzenia wielkości sztuki i nigdy go nie będzie" ${ }^{\prime 125}$. Z tego powodu, twierdzi Kandyński, nie można wierzyć nikomu - obojętne, czy o chodziłoby o laika, artystę, czy kompetentnego teoretyka - kto twierdziłby, że wykrył w dziele jakiś obiektywny błąd. Można jedynie twierdzić, że nie udało się poznać takiego właśnie zastosowania środków, jeżeli nie doprowadziły one do celu, jakim jest wewnętrzne przeżycie duchowe. W sztuce bowiem wszystkie środki są względne, a nie absolutne, i właśnie dzięki tej właściwości możliwe jest jej niewyczerpywalne bogactwo ${ }^{126}$.

Kłopot stanowi również to, że istotne szczegóły w sztuce są nieopisywalne, ponieważ każdy opis, jakkolwiek byłby adekwatny, zakłada tę wcześniejszą źródłową fenomenologiczną donację afektywności, która jest niekomunikowalna językowo ${ }^{127}$. Zauważmy, że choć transcendentalne Życie rozumiane jako "Słowo Życia” - czyli jako Logos z Prologu Ewangelii św. Jana (J 1, 1) - jest niewidzialne, to jego zjawiska (projekcje) ukazujące się w zewnętrzności świata - już jako "słowo świata” (logos) poddają się opisowi ${ }^{128}$. Jednak zawsze te opisy, oceny czy wartościowania będą „odrealnieniem” dzieła pod nieobecność jego rzeczywistego,

121 Por. tamże, 59, 81-84.

122 Kandyński, O duchowości w sztuce, 74.

123 Por. Henry, La barbarie, 43-44, 112-113.

124 Kandyński, O duchowości w sztuce, 84, przypis dolny.

125 Kandyński, Eseje o sztuce i artystach, 122.

126 Por. tamże, 149.

127 Por. Kandyński, O duchowości w sztuce, 98; Henry, O fenomenologii, 191.

128 Por. Henry, Wcielenie, 366; Henry, Stowa Chrystusa, 97, 104, 133-134. 
czyli afektywnego, samooddziaływania Życia w cielesności Sobości ${ }^{129}$. Co więcej, skoro abstrakcyjna treść sztuki - czyli afektywne doznanie Życia - wymyka się wszelkiej myśli, to nie odnajdziemy tej niewidzialnej treści w pamięci, a to oznacza, że nie ma również żadnego zapomnienia i przypomnienia Życia, mimo że ono nas nigdy nie opuszcza ${ }^{130}$.

Ostatecznie okazuje się, że jedyne, co możemy powiedzieć o wartości dzieła sztuki, to: „ten obraz jest namalowany dobrze, który żyje pełnym życiem wewnętrznym"131. Co najmniej z dwóch powodów problematyczna staje się wówczas wciąż żywa w estetyce, działaniach artystów oraz $\mathrm{w}$ potocznym rozumieniu doświadczenia estetycznego koncepcja „wczucia”. Po pierwsze w fenomenologii Henry'ego sztuka nie wyraża stanów psychicznych jakiejś konkretnej osoby-twórcy, lecz transcendentalny, doznaniowy i afektywny wymiar Życia ${ }^{132}$, a po drugie dzieło traci na ważności jako artefakt, ponieważ przedmiot zewnętrzny nie posiada żadnego życia i nie jest zdolny do jakichkolwiek uczuć. We Wcieleniu przeczytamy: "Żadnemu przedmiotowi nigdy nie dane było zaznać doświadczenia bycia dotkniętym"133. W przyrodzie nie ma żadnych wartości, gdyż te przynależą jedynie Życiu, które jest źródłem kultury i jedyną uniwersalną zasadą ewaluacji ${ }^{134}$. Kryteria wartościowania sztuki sprowadzone do subiektywnych wrażeń lokują się wyłącznie w immanencji Sobości zrodzonej przez Życie, choć nie oznacza to jeszcze, że subiektywne ja jest szczelną monadą bez okien. Każda Sobość jest tak samo zrodzona przez absolutne Życie, a te poszczególne Sobości tak samo poznają Życie poprzez swoją cielesność (la chair), co z kolei stanowi warunek transcendentalny wspólnoty jako wszelkiej możliwej relacji pomiędzy Sobościami ${ }^{135}$. Ma to swe dalsze konsekwencje w odniesieniu do sztuki, ponieważ gdy subiektywna doznaniowość (pathos) staje się jedynym miernikiem wartościującym dzieła artystyczne, to wówczas zacierają się różnice, wynikające z dziejowego rozwoju kultury. Tym sposobem cała sztuka okazuje się współczesna, ponieważ każde dzieło opiera się na tej samej „zasadzie wewnętrznej konieczności”

129 Por. Henry, Wcielenie, 272-273; Henry, La barbarie, 65-67.

130 Henry mówi o pamięci bezpamiętnej, która zjednoczyła nas z Życiem od zawsze i na zawsze i właśnie ta niepamiętna pamięć życia, która nas z nim łączy, jest samym życiem w swym patosie, czyli naszą cielesnością; por. Henry, Wcielenie, 326; Henry, O fenomenologii, 186.

${ }_{131}$ Kandyński, O duchowości w sztuce, 123.

132 Por. Murawska, „Samo źródło źródłowości”: 299.

133 Henry, Wcielenie, 359.

${ }^{134}$ Por. tamże, 380; Michel Henry, „Etyka i kryzys współczesnej kultury”, przeł. Monika Murawska, w: Michel Henry - fenomenolog życia, red. Andrzej Gielarowski, Robert Grzywacz (Kraków: Wyższa Szkoła Filozoficzno-Pedagogiczna „Ignatianum", Wydawnictwo WAM, 2010), 77-79. Por. także Hart, „Teoria fenomenologiczna i krytyka kultury": 371; Leclercq, „Droga ku słowom Boga”: 389-390.

135 Henry, O fenomenologii, 255-256. 
oraz wewnętrznej wrażeniowości (doznaniowości) Życia ${ }^{136}$. Nawiązując explicite do Sørena Kierkegaarda, Henry stwierdza:

I tak rzeczywista relacja może się ustanowić między takimi transcendentalnymi Sobościami, które nigdy się nie widziały i należą do różnych epok. Życiem człowieka może wstrząsnać lektura książki z innego stulecia, nieznanego autorstwa. Jakiejkolwiek jednostce może stać się współczesne wydarzenie, które zaszło dwa tysiące lat temu ${ }^{137}$.

Zauważmy jednak, że z drugiej strony Henry przyznaje, że bez znajomości tradycji danej kultury - na przykład chrześcijańskiej - niemożliwe byłoby poznanie "quasi-totalności" (quasi-totalité) arcydzieł malarstwa zachodniego, dlatego, aby w pełni docenić ten typ sztuki, konieczna jest edukacja i dookreślenie dziejowo-kulturowe ${ }^{138}$.

Koncepcje sztuki Kandyńskiego i Henry'ego nieustannie balansują na granicy z religijnością. Przekroczenie tej granicy doprowadziłoby nas do myślenia teozoficznego, teologicznego bądź chrystologicznego, a to już nie mieściłoby się $\mathrm{w}$ wyznaczonym zakresie tematycznym tego artykułu. Jednak by nie przemilczeć zupełnie tego wielkiego zagadnienia, jakim jest teologia sztuki, czyli objawienie Boga poprzez sztukę, odnotujmy przynajmniej jedną istotną kwestię. Według Kandyńskiego artysta powinien uważać się za podporządkowanego we wszystkim sługę, którego obowiązki są wielkie i święte, po to, aby sztuka mogła pozostawać w służbie Boskości ${ }^{139}$. Nauka o sztuce ma z kolei doprowadzić do szerokiej syntezy, sięgającej w konsekwencjach daleko poza granice sztuki „(...) w dziedzinę Jedności tego, co Ludzkie, i tego, co Boskie"140. To tu właśnie tkwi fundamentalna trudność, którą zauważa również Henry: w jaki sposób ta jedność Boga (absolutnego Życia) i naszego życia może objawić się poprzez sztukę? ${ }^{141}$ Zasadniczo jest to pytanie o tożsamość Boga i człowieka, a także o możliwość (samo-)objawienia religijnego dzięki sztuce. Sztuka w filozofii Henry'ego, objawiając niewidzialne Życie, objawia zarazem Boga, którego istnienie okazuje się pewniejsze

136 Por. Henry, Voir l'invisible, 130-131; Henry, La barbarie, 218-219; Henry, „Sztuka i fenomenologia życia": 166-167.

137 Henry, Wcielenie, 424. Por. także Henry, O fenomenologii, 257; Leclercq, „Droga ku słowom Boga”: 385-386, 388; Yampolskaya, „Metamorphoses”: 164-165.

138 Por. Henry, „Zobaczyć niewidzialne”: 353; Murawska, „Piękno nieintencjonalne", 224-225.

${ }^{139}$ Kandyński, O duchowości w sztuce, 76, 125-126.

140 Kandyński, Punkt i linia a płaszczyzna, 20.

141 Por. Henry, "Zobaczyć niewidzialne”: 353. Zauważmy na marginesie, że Kandyński był przekonany o możliwości transpozycji zjawisk każdego wymiaru świata na odpowiednie formy artystyczne; por. Kandyński, Punkt i linia a płaszczyzna, 105, przypis dolny; por. także Kandyński, Eseje o sztuce i artystach, 107; Rejniak-Majewska, Chaosmos, 218. 
niż istnienie widzialnego świata ${ }^{142}$. Poszczególna Sobość zdefiniowana poprzez transcendentalne Życie, czyli poprzez żywe Słowo Boga, jest nie tylko Synem Boga ${ }^{143}$, ale - jak dowiadujemy się z wykładu wygłoszonego przez Henry'ego w Akademii Sztuk Pięknych w Monachium 14 listopada 2000 roku - „W Głębi Nocy nasze żywe ciało jest Bogiem”"144. Właśnie to stwierdzenie budzi największe kontrowersje nie tylko wśród fenomenologów, ale także chrześcijan, domagając się dalszych i precyzyjniejszych rozjaśnień ${ }^{145}$.

\section{Zakończenie}

Fenomenologia życia Michela Henry'ego stanowi rozwinięcie głównych założeń filozofii sztuki Wasyla Kandyńskigo. W warstwie fenomenologii sztuki Henry przejmuje bez znaczących modyfikacji i krytyki całe dziedzictwo teoretyczno-filozoficzne Kandyńskiego, ale wyprowadza z tego programu daleko idące konsekwencje. Jak się okazuje, wypowiedź Kandyńskiego o mającej nastąpić syntezie, daleko przekraczającej granice sztuki, była antycypacją filozofii Henry'ego, w której została zespolona artystyczno-filozoficzna wizja sztuki z fenomenologią życia. Projekt ten - jeśli uwzględniamy prace C'est moi la vérité146, Wcielenie oraz Stowa Chrystusa - nabiera w filozofii Henry'ego wyraźne znamiona teologiczne. Spotkanie sztuki i teologii nie jest oczywiście niczym nowym w dziejach filozofii, ale w refleksji estetycznej Michela Henry'ego złączenie fenomenologii życia i chrystologii prowadzi do radykalnych tez - dużo śmielszych, niż spotykamy u Kandyńskiego - które budzą uzasadnione polemiki. Wypada również stwierdzić, że wątki teozoficzne u Kandyńskiego - zaznaczane przez niego zazwyczaj dyskretnie - wykazują na ogół tylko „zewnętrzne” podobieństwo do teologicznej wykładni sztuki

142 Por. Henry, Wcielenie, 172.

143 Por. Henry, „Sztuka i fenomenologia życia”: 171.

${ }^{144}$ Henry, O fenomenologii, 111. Por. także Gabrielle Dufour-Wierusz Kowalska, „Michel Henry. Objawienie fenomenologiczne a objawienie chrześcijańskie”, przeł. Robert Grzywacz, w: Michel Henry - fenomenolog życia, red. Andrzej Gielarowski, Robert Grzywacz (Kraków: Wyższa Szkoła Filozoficzno-Pedagogiczna „Ignatianum”, Wydawnictwo WAM, 2010), 175-178; Andrzej Gielarowski, „Fenomenologia i teologia w filozofii człowieka Michela Henry'ego", w: Michel Henry - fenomenolog życia, red. Andrzej Gielarowski, Robert Grzywacz (Kraków: Wyższa Szkoła Filozoficzno-Pedagogiczna „Ignatianum”, Wydawnictwo WAM, 2010), 202.

145 Por. Karol Tarnowski, „Samo-pobudzenie i Bóg”, w: Michel Henry - fenomeno$\log \dot{z} y c i a$, red. Andrzej Gielarowski, Robert Grzywacz (Kraków: Wyższa Szkoła Filozoficzno-Pedagogiczna „Ignatianum”, Wydawnictwo WAM, 2010), 231.

146 Michel Henry, C'est moi la vérité: Pour une philosophie du Christianisme (Paris: Editions du Seuil, 1996). 
Henry'ego, a w warstwie szczegółowej łatwo odnaleźć różnice, które nie pozwalają utożsamić „,spirytualizmu” z chrześcijaństwem.

Opozycja materializmu i duchowości u Kandyńskiego w sposób szczególny odpowiada przeciwstawieniu świata i życia u Henry'ego. Przy ostrożnym traktowaniu takich pojęć, jak „abstrakcja” lub „konkretność" - u Henry'ego każde dzieło sztuki jest abstrakcyjne, natomiast u Kandyńskiego dzieła sztuki są „konkretne” - widać oczywiście istotne paralelizmy, lecz stopień redukcji zewnętrznego świata na rzecz wewnętrznego życia duchowego nie jest u obu autorów identyczny. Wydaje się, że abstrahowanie sztuki od świata nie jest aż tak radykalne w wypowiedziach Kandyńskiego, jak sugeruje to sam Henry.

U obu myślicieli niezwykle charakterystyczna jest jeszcze jedna cecha, w której należy upatrywać doniosłości prezentowanej tutaj filozofii sztuki. Tą cechą jest eksploracja niewidzialnej, tj. pozamaterialnej i duchowej, sfery sztuki. Takie ukierunkowanie rozważań estetyczno-filozoficznych prowadzi wprost do zapytywania nie tylko o istotę dzieła sztuki, ale także o istotę człowieka. Kandyński i Henry zgodnie uważali, że sztuka ma zdolność nadawania życiu wartości, która ubogaca człowieka w warstwie duchowej i czyni go prawdziwie żyjącą Sobością. Afektywne doznawanie dzieł sztuki okazuje się swoistą drogą do głębokiego życia wewnętrznego, w którym źródłowo odnajdujemy samych siebie. Takie rozumienie sztuki wykracza poza wąsko rozumianą estetykę filozoficzna, choć nie zrywa całkowicie z nią więzów. Fenomenologiczne przekraczanie ram estetyki nie poprzestaje na podmiotowo-przedmiotowych analizach naszego sposobu doświadczania dzieł sztuki, lecz zmierza ostatecznie do rozpoznania najgłębszego źródła naszego życia. Analizy estetyczne nadal pozostają niezbędną metodologią badań dzieł sztuki, lecz okazują się one niewystarczające $\mathrm{w}$ dążeniu do uchwycenia istoty sztuki i jej znaczenia w życiu człowieka. Z tego właśnie powodu filozofia sztuki Wasyla Kandyńskiego oraz reinterpretacja tej filozofii w fenomenologicznej perspektywie Michela Henry'ego stanowią wartościową propozycje poszerzenia klasycznych rozważań estetyki o wymiar egzystencjalny, aksjologiczny oraz religijny.

\section{Bibliografia}

Capelle Philippe. 2010. „Fenomenologia i życie w myśli Michela Henry'ego', przeł. Siostry Betanki. W: Michel Henry - fenomenolog życia, red. Andrzej Gielarowski, Robert Grzywacz, 13-36. Kraków: Wyższa Szkoła Filozoficzno-Pedagogiczna „Ignatianum”. Wydawnictwo WAM.

Descartes René. 2001. Medytacje o pierwszej filozofii, przeł. Maria i Kazimierz Ajdukiewiczowie. Kęty: Wydawnictwo ANTYK. 
Descartes René. 2001. Namiętności duszy, przeł. Ludwik Chmaj. Kęty: Wydawnictwo ANTYK.

Drwięga Marek. 2012. „Cielesność i Życie, czyli o filozofii Michela Henry'ego". W: Michel Henry, Wcielenie. Filozofia ciała, przeł. Małgorzata Frankiewicz, Dariusz Adamski, 9-28. Kraków: Tyniec. Wydawnictwo Benedyktynów.

Dufour-Wierusz Kowalska Gabrielle. 2010. „Michel Henry. Objawienie fenomenologiczne a objawienie chrześcijańskie", przeł. Robert Grzywacz. W: Michel Henry - fenomenolog życia, red. Andrzej Gielarowski, Robert Grzywacz, 163-184. Kraków: Wyższa Szkoła Filozoficzno-Pedagogiczna "Ignatianum”. Wydawnictwo WAM.

Gielarowski Andrzej. 2010. „Fenomenologia i teologia w filozofii człowieka Michela Henry'ego". W: Michel Henry - fenomenolog życia, red. Andrzej Gielarowski, Robert Grzywacz, 185-214. Kraków: Wyższa Szkoła Filozoficzno-Pedagogiczna „Ignatianum”. Wydawnictwo WAM.

Gielarowski Andrzej. 2016. Kryzys kultury, kryzys człowieka. Kraków: Wydawnictwo WAM.

Gilbert Paul. 2010. „Michel Henry i immanencja”, przeł. Robert Grzywacz. W: Michel Henry - fenomenolog życia, red. Andrzej Gielarowski, Robert Grzywacz, 105-122. Kraków: Wyższa Szkoła Filozoficzno-Pedagogiczna "Ignatianum". Wydawnictwo WAM.

Hart James G. 2012. „Teoria fenomenologiczna i krytyka kultury. Czytanie La Barbarie Michela Henry'ego", przeł. Paulina Sosnowska. Przegląd Filozoficzno-Literacki 34: 361-378.

Henry Michel. 1996. C'est moi la vérité: Pour une philosophie du Christianisme. Paris: Editions du Seuil.

Henry Michel. 2004. La barbarie. Paris: Quadrige/PUF.

Henry Michel. 2005. Voir l'invisible. Sur Kandinsky. Paris: Quadrige/ PUF.

Henry Michel. 2006. „Fenomenologia nie-intencjonalna: zadanie fenomenologii przyszłości", przeł. Jacek Migasiński. W: Fenomenologia francuska. Rozpoznania, interpretacje, rozwinięcia, red. Iwona Lorenc, Jacek Migasiński, 418-437. Warszawa: IFiS PAN.

Henry Michel. 2007. O fenomenologii, przeł. Marek Drwięga. Warszawa: Wydawnictwo IFiS PAN.

Henry Michel. 2010. „Etyka i kryzys współczesnej kultury”, przeł. Monika Murawska. W: Michel Henry - fenomenolog życia, red. Andrzej Gielarowski, Robert Grzywacz, 73-81. Kraków: Wyższa Szkoła Filozoficzno-Pedagogiczna „Ignatianum”. Wydawnictwo WAM.

Henry Michel. 2010. „Etyka i religia w fenomenologii Życia”, przeł. Monika Murawska. W: Michel Henry - fenomenolog życia, red. Andrzej Gielarowski, Robert Grzywacz, 149-161. Kraków: Wyższa Szkoła Filozoficzno-Pedagogiczna „Ignatianum”. Wydawnictwo WAM.

Henry Michel. 2011. „Zobaczyć niewidzialne. O Kandinskym”, przeł. Dorota Molińska. Artium Quaestationes 22: 351-367. 
Henry Michel. 2012. „Czy pojęcie duszy ma sens?”, przeł. Maja Chmura, Filip Taranienko, przekład przejrzał i poprawił Jacek Migasiński. Przeglad Filozoficzno-Literacki 34: 67-91.

Henry Michel. 2012. „Przedmowa do wydania włoskiego Genealogii psychoanalizy", przeł. Paweł Orłowski. Przeglą Filozoficzno-Literacki 34: 19-26.

Henry Michel. 2012. Słowa Chrystusa, przeł. Kazimierz Mrówka. Tarnów: Wydawnictwo Diecezji Tarnowskiej Biblos.

Henry Michel. 2012. „Sztuka i fenomenologia życia”, przeł. Monika Murawska. Przegląd Filozoficzno-Literacki 34: 157-179.

Henry Michel. 2012. „Videre videor", przeł. Maja Chmura, przekład przejrzał i poprawił Jacek Migasiński. Przeglad Filozoficzno-Literacki 34: 37-66.

Henry Michel. 2012. Wcielenie. Filozofia ciała, przeł. Małgorzata Frankiewicz, Dariusz Adamski. Kraków: Tyniec. Wydawnictwo Benedyktynów.

Husserl Edmund. 2013. Doświadczenie i sąd, przeł. Bogdan Baran. Warszawa: Fundacja Aletheia.

Husserl Edmund. 2017. Kryzys nauk europejskich i fenomenologia transcendentalna, przeł. Sławomira Walczewska. Kraków: Vis-à-vis Etiuda.

Kandyński Wasyl. 1978. Obrazy, przeł. Jerzy Stankiewicz. W: Luigi Rognoni, Wiedeńska szkoła muzyczna, przeł. Henryk Krzeczkowski, 481-484. Kraków: Polskie Wydawnictwo Muzyczne.

Kandyński Wasyl. 1991. Eseje o sztuce i artystach, przeł. Ewa Sagan. Kraków: Politechnika Krakowska im. Tadeusza Kościuszki.

Kandyński Wasyl. 1996. O duchowości w sztuce, przeł. Stanisław Fijałkowski. Łódź: Państwowa Galeria Sztuki w Łodzi.

Kandyński Wasyl. 2019. Punkt i linia a płaszczyzna, przeł. Stanisław Fijałkowski. Łódź: Wydawnictwo Oficyna.

Kruszyńska Sabina. 2016. „Ugruntowanie podmiotu w fenomenologii radykalnej Michela Henry'ego". Miscellanea Anthropologica et Sociologica 17: 71-81.

Kruszyńska Sabina. 2018. Kulturalny barbarzyńca. Fenomenologia radykalna Michela Henry'ego jako filozofia sztuki życia. Kraków: TAiWPN Universitas.

Leclercq Jean. 2012. „Droga ku słowom Boga. Michel Henry i nauka chrześcijańska", przeł. Monika Murawska. Przegląd Filozoficzno-Literacki 34: 379-396.

Lorenc Iwona. 2006. „Ścieżki ku rzeczom samym współczesnej fenomenologii francuskiej". W: Fenomenologia francuska. Rozpoznania, interpretacje, rozwinięcia, red. Iwona Lorenc, Jacek Migasiński, 30-66. Warszawa: IFiS PAN.

Marion Jean-Luc. 1996. „The Saturated Phenomenon”. Philosophy Today 40, 1: 103-124.

Marion Jean-Luc. 2007. Będac danym. Esej z fenomenologii donacji, przeł. Wojciech Starzyński. Warszawa: IFiS PAN.

Marion Jean-Luc. 2008. The Visible and the Revealed, przeł. Christina M. Gschwandtner, Thomas A. Carlson, John Conley, Danielle Poe, Arianne Conty, Jeffrey F. Kosky. New York: Fordham University Press. 
Marion Jean-Luc. 2016. Givenness and Revelation, przeł. Stephen E. Lewis. Oxford-New York: Oxford University Press.

Merleau-Ponty Maurice. 1996. Oko i umyst, przeł. Stanisław Cichowicz. W: Maurice Merleau-Ponty, Oko i umyst. Szkice o malarstwie, przeł. Stanisław Cichowicz, Maryna Ochab, Ewa Bieńkowska, Joanna Skoczylas, 15-67. Gdańsk: Wydawnictwo Słowo obraz/terytoria.

Merleau-Ponty Maurice. 1996. Widzialne i niewidzialne, przeł. Małgorzata Kowalska, Jacek Migasiński, Renata Lis, Iwona Lorenc. Warszawa: Fundacja Aletheia.

Migasiński Jacek. 2012. „Kartezjusz podług Henry’ego: początek fenomenologii". Przeglad Filozoficzno-Literacki 34: 201-218.

Mumford Lewis. 2012. Mit maszyny. T. 1, przeł. Michał Szczubiałka. Warszawa: Wydawnictwo Naukowe PWN.

Mumford Lewis. 2014. Mit maszyny. T. 2, przeł. Michał Szczubiałka. Warszawa: Wydawnictwo Naukowe PWN.

Murawska Monika. 2006. „Sztuka, która pozwala zobaczyć niewidzialne. Maurice Merleau-Ponty o malarstwie Cézanne'a i Michel Henry o abstrakcji Kandinskiego". Przeglad Filozoficzno-Literacki 14: 133-154.

Murawska Monika. 2010. „Filozofia źródłowa «contra» antropologia. Fenomen kultury w ujęciu Michela Henry'ego". W: Michel Henry - fenomeno$\log \dot{z}$ ycia, red. Andrzej Gielarowski, Robert Grzywacz, 123-146. Kraków: Wyższa Szkoła Filozoficzno-Pedagogiczna „Ignatianum”. Wydawnictwo WAM.

Murawska Monika. 2011. Filozofowanie z zamkniętymi oczami. Fenomenologia ciała Michela Henry'ego. Wrocław: Wydawnictwo Uniwersytetu Wrocławskiego.

Murawska Monika. 2011. „Piękno nieintencjonalne. Fenomenologia sztuki Michela Henry'ego". W: Między przedmiotowością a podmiotowością: intencjonalność w fenomenologii francuskiej, red. Andrzej Gielarowski, Robert Grzywacz, 209-226. Kraków: Akademia Ignatianum, Wydawnictwo WAM.

Murawska Monika. 2012. „Obnażyć sztukę. Fenomen dzieła sztuki w fenomenologii Jeana Luca Mariona i Henriego Maldineya". W: Fenomen i przedstawienie. Francuska estetyka fenomenologiczna. Założenial zastosowanial konteksty, red. Iwona Lorenc, Mateusz Salwa, Piotr Schollenberger, 265-286. Warszawa: Wydawnictwo IFiS PAN.

Murawska Monika. 2012. „Post-fenomenologia jako źródło cierpien”. Przeglad Filozoficzno-Literacki 34: 9-18.

Murawska Monika. 2012. „Samo źródło źródłowości. Kategoria jawienia się w fenomenologii Michela Henry'ego i Henri Maldineya". Przegląd Filozoficzno-Literacki 34: 293-314.

Murawska Monika. 2014. „Meandry cielesności. Różne oblicza fenomenologii ciała". W: Wprowadzenie do fenomenologii. Interpretacje, zastosowania, problemy. T. 1, red. Witold Płotka, 444-483. Warszawa: Wydawnictwo IFiS PAN. 
Petit Jean-François. 2011. „Michel Henry: intencjonalność między marksizmem a chrześcijaństwem", przeł. M. Murawska. W: Między przedmiotowościa a podmiotowością: intencjonalność w fenomenologii francuskiej, red. Andrzej Gielarowski, Robert Grzywacz, 365-378. Kraków: Akademia Ignatianum. Wydawnictwo WAM.

Pokropski Marek. 2012. „Husserl i Henry - spór o intencjonalność”. Przegląd Filozoficzno-Literacki 34: 229-249.

Rejniak-Majewska Agnieszka. 2019. „Chaosmos, czyli o gramatyce i fizjonomice form". W: Wasyl Kandyński, Punkt i linia a płaszczyzna, przeł. Stanisław Fijałkowski, 198-223. Łódź: Wydawnictwo Oficyna.

Schopenhauer Arthur. 1995. Świat jako wola i przedstawienie. T. 2, przeł. Jan Garewicz. Warszawa: Wydawnictwo Naukowe PWN.

Schönberg Arnold, Kandinsky Wassily. 1980. Briefe, Bilder und Dokumente einer außergewöhnlichen Begegnung, red. Jelena Hahl-Koch. Salzburg-Wien: Residenz Verlag.

Selz Peter. 1957. „The Aesthetic Theories of Wassily Kandinsky and Their Relationship to the Origin of Non-Objective Painting". The Art Bulletin 39, 2: 127-136.

Spengler Oswald. 2014. Zmierzch Zachodu, przeł. Józef Marzęcki. Warszawa: Wydawnictwo Aletheia.

Starzyński Wojciech. 2014. Neokartezjanizm fenomenologii francuskiej. Warszawa: IFiS PAN.

Stoker Wessel. 2012. Where Heaven and Earth Meet, przeł. Henry Jansen. Amsterdam-New York: Editions Rodopi B.V.

Tarnowski Karol. 2010. „Samo-pobudzenie i Bóg”. W: Michel Henry - fenomenolog życia, red. Andrzej Gielarowski, Robert Grzywacz, 215-232. Kraków: Wyższa Szkoła Filozoficzno-Pedagogiczna „Ignatianum”, Wydawnictwo WAM.

Yampolskaya Anna. 2018. „Metamorphoses of the Subject: Kandinsky Interpreted by Michel Henry and Henri Maldiney". Avant 9, 2: 157-167.

Witkiewicz Stanisław Ignacy. 2002. Nowe formy w malarstwie i wynikajace stad nieporozumienia. Szkice estetyczne. Warszawa: PIW.

Zahavi Dan. 2012. „Michel Henry i fenomenologia niewidzialnego”, przeł. Paulina Sosnowska. Przeglad Filozoficzno-Literacki 34: 315-333.

\section{Streszczenie}

Sztuka - obok etyki i religii - zajmuje poczesne miejsce w fenomenologii życia Michela Henry'ego. Polemizując z fenomenologią Edmunda Husserla i Martina Heideggera oraz analizując twórczość i prace teoretyczne Wasyla Kandyńskiego, Henry doszedł do wniosku, że treścią sztuki jest niewidzialne życie. W konsekwencji sztuka, sama niewidzialna, a jednak objawiająca Życie, okazuje się sposobem nieintencjonalnego doznania (pathos) Życia w jego transcendentalnej afektywności. Radykalna immanencja doznaniowości sztuki stoi w jaskrawej 
opozycji wobec widzialnego świata zewnętrznego i tym samym wyznacza fenomenologii nowy obszar badań nad doświadczeniem estetycznym, a przy tym także religijnym. W artykule wskazuję na trudności i ograniczenia ontologiczne, epistemologiczne oraz aksjologiczne koncepcji sztuki Michela Henry'ego oraz Wasyla Kandyńskiego.

Słowa kluczowe: afektywność, doznaniowość (pathos), fenomenologia, Henry, immanencja, Kandyński, sztuka, Życie

\section{Art as Revelation of Life in Michel Henry's Phenomenology}

\section{Summary}

Alongside with ethics and religion, art occupies a prominent place in Michel Henry's phenomenology of life. His opposition to Husserl and Heidegger, and his analyses of Wassily Kandinsky's paintings and theoretical works, led Henry to the conclusion that the content of art is the 'invisible life'. As a consequence, art-itself invisible though at the same time revealing the Life-becomes a means of achieving a non-intentional experience (pathos) of Life in its transcendental affectivity. The radical immanence of experiencing art stands in sharp contrast to the visible external world, thus opening new directions in phenomenological study of both aesthetic and religious experience. In this article, I point out the ontological, epistemological and axiological limitations of Henry's and Kandinsky's art theory.

Keywords: affectivity, experience (pathos), phenomenology, Henry, immanence, Kandinsky, art, Life 